\title{
All You Need Is Time? Discrepancies between the European Court of Human Rights Case LaW and Liberal Normative TheOry ON LONG-TeRm Migrants
}

\author{
Başak Çali ${ }^{*}$
}

This contribution is a reflection on the article 'Rights in Immigration: The Veil as a Test Case' by Gila Stopler, originally published in (2010) 43 Israel Law Review 183.

This article, departing from Gila Stopler's 'Rights in Immigration: The Veil as a Test Case', published in the Israeli Law Review in 2010, reviews how the time spent by a long-term migrant, irrespective of legal status, normatively figures in liberal theories of migration and in the case law of the European Court of Human Rights (ECtHR). The article detects that in contemporary liberal theories, assigning an independent normative value to time spent by the migrant in the receiving country is a key move in balancing the competing interests of migrants and of the migrant-receiving country, where the right of the country to regulate migration is taken as given: the longer a migrant is present in a country, the stronger her interests become in receiving citizenship status or treatment akin to citizens. The article then surveys the case law of the ECtHR relating to long-term migrants. It finds that time is often one of multiple normative considerations in the balancing exercise, in conjunction with whether a migrant has achieved social integration in the migrant-receiving country and whether the right of the receiving community to regulate migration for reasons of affording citizenship, national security or distributive justice is paramount. The article argues that the lack of an independent normative weight afforded to time in the case law of the ECtHR is not merely a tension between the translation of liberal normative theory to legal policy. It also shows a deeper tension in liberal theories of migration between national liberalism and cosmopolitan liberalism.

Keywords: jus temporis, long-term migrants, liberal theories of migration, European Court of Human Rights

\section{INTRODUCTION}

Gila Stopler's 'Rights in Immigration: The Veil as a Test Case' was published in the Israel Law Review in 2010. In this article Stopler put forward a framework to assess normatively the place of rights in immigration within the context of liberal theories of justice. ${ }^{1}$ Stopler held that such rights must be thought of in terms of stages rather than their totality and proposed three

\footnotetext{
* Başak Çalı, Hertie School of Governance, Berlin; and Koç University, Center for Global Public Law, Istanbul. cali@hertie-school.org.

${ }^{1}$ Gila Stopler, 'Rights in Immigration: The Veil as a Test Case' (2010) 43 Israel Law Review 183. Liberal theorists disagree over the moral relevance of borders and whether they should be taken as givens (despite their historical arbitrariness) for a liberal theory of justice broadly, or of migration more specifically, or not. With respect to the former position, see John Rawls, The Law of Peoples (Cambridge University Press 2001); David Miller, 'Immigrants, Nations and Citizenship' (2008) 16 Journal of Political Philosophy 371. With respect to the latter position and the review of the former position, see Philip Cole, 'Beyond Reason: The Philosophy and Politics of Immigration' (2014) 17 Critical Review of International Social and Political Philosophy 503.
} 
normatively relevant stages of immigration for liberal democratic states: entry into a country (Stage I); request for citizenship (Stage II); and residence in the country of immigration (Stage III). ${ }^{2}$ Stopler argued that rights in immigration, in an established legal and cultural community committed to universal respect for basic rights, must be assessed based on the stage of immigration in which a migrant finds herself. While liberal democracies had a right to regulate immigration, the longer a migrant is in a country, the more weighty her interests become in requiring equal treatment - that is, citizen-like treatment or actual citizenship. In this article, Stopler also reviewed cases from the European Court of Human Rights (ECtHR or the Court). She showed that there existed discrepancies between how the Court handled cases involving rights in migration and liberal normative theory. She highlighted that, under the margin of appreciation doctrine, the deference that the Court accords to the rights of migrant-receiving states in addressing the cultural and religious rights of long-term migrants was not normatively justifiable from the perspective of liberal theory. ${ }^{3}$

Seven years on, the article and the two-pronged issue on which it focused - immigration and veils in Europe - remain highly relevant. Politically, migration control is firmly on the European agenda. People fleeing persecution and conflict, as well as those searching for better life prospects for themselves and their families, continue to try to reach Europe, often at great risk to their lives. ${ }^{4}$ The questions of who should remain in liberal democracies, be they migrants or refugees, and on what terms, unceasingly spark debate. ${ }^{5}$ There is much talk and action about preventing migrants from arriving in Europe, ${ }^{6}$ the migrant's duty to integrate, ${ }^{7}$ and the state's right to expel or even strip citizenship ${ }^{8}$ from those who disturb the public order. Conditional stay ${ }^{9}$ and

\footnotetext{
${ }^{2}$ Stopler, ibid 187-91.

3 ibid 201-04.

${ }^{4}$ International Organization for Migration, Global Migration Data Analysis Cenre, 'The Central Mediterranean Route: Deadlier than Ever', Data Briefing Series Issue No 3, June 2016, https://publications.iom.int/system/ files/pdf/gmdac_data_briefing_series_issue3.pdf.

${ }^{5}$ Arash Abizadeh, 'Democratic Theory and Border Coercion: No Right to Unilaterally Control Your Own Borders' (2008) 36 Political Theory 37; David Miller, 'Why Immigration Controls Are Not Coercive: A Reply to Arash Abizadeh' (2010) 38 Political Theory 111; Michael Blake, 'Immigration, Jurisdiction, Exclusion' (2013) 41 Philosophy \& Public Affairs 103; Philip Cole, 'Taking Moral Equality Seriously: Egalitarianism and Immigration Controls' (2012) 8 Journal of International Political Theory 121; Joseph Carens, The Ethics of Immigration (Oxford University Press 2013); Cathryn Costello, Human Rights of Migrants and Refugees in European Law (Oxford University Press 2015); Marie Bénédicte Dembour, When Humans Become Migrants: Study of the European Court of Human Rights with an Inter-American Counterpoint (Oxford University Press 2015); Bastian Vollmer, 'The Continuing Shame of Europe: Discourses on Migration Policy in Germany and the UK' (2017) 5 Migration Studies 49.

${ }^{6}$ ECtHR, Hirsi Jamaa and Others v Italy, App no 27765/09, 23 February 2012; European Council, 'EU-Turkey Statement', Press Release 144/16, 18 March 2016, http://www.consilium.europa.eu/en/press/press-releases/2016/ 03/18-eu-turkey-statement.

${ }^{7}$ Alexandra Xanthaki, 'Against Integration, for Human Rights' (2016) 20 The International Journal of Human Rights 815.

${ }^{8}$ ECtHR, K2 v United Kingdom, App no 42387/13, 7 February 2017 (stripping of UK citizenship from a UK/ Sudan dual citizen on the ground of invovlement in terrorism).

${ }^{9}$ ECtHR, Jeunesse v The Netherlands, App no 12738/10, 3 October 2014.
} 
expulsion of migrants, ${ }^{10}$ as well as restrictions on migrants' cultural and religious rights ${ }^{11}$ have seen continuing litigation, in particular, before the ECtHR.

My aim in this article is to depart from Stopler's account of how rights in immigration ought to be determined within the normative framework of liberal theories of justice, which places significance on the length of time migrants spend in a receiving country. I aim to assess the convergence between the liberal normative account put forward by Stopler and the jurisprudence of the Court with respect to the right-to-remain cases of long-term migrants in Europe. In so doing, I focus on cases brought by migrants who have lived in Europe for five years or more, demanding that they should be treated equally with any other member of the political community based on the length of their stay in the respective country. ${ }^{12}$

The argument in this article is twofold. First, I argue that there are important discrepancies between Stopler's liberal normative framework, which places special emphasis on the normative significance of the length of stay, and the case law of the Court. In her account Stopler supports the principle of jus temporis for identifying rights in migration: the longer a migrant resides in a country, the stronger his or her interest becomes to be treated equally with citizens. In the case law of the ECtHR, however, length of stay is not a particularly weighty consideration, but is one consideration of many in adjudicating the rights of long-term migrants. Secondly, I argue that this discrepancy is not simply because of the wide margin of appreciation the Court accords to states in the area of migration; thus it is not merely a feature or failure of legal policy. Instead, I propose that the liberal normative theory is ambiguous in offering normative guidance as to how significant a consideration time should be, in particular with regard to other countervailing considerations such as the migrant's legal status or the risks to national security. While some theorists, like Stopler, advocate for normative significance to be given to length of time regardless of the legal status of the migrant, they do not address how time should interact with other considerations in the balancing exercise.

In what follows, I first offer a brief account of Stopler's three stages of immigration and her sliding-scale approach to rights in migration, focusing on a migrant's length of stay as leading to a corresponding increase in their rights. In Section 3 I turn to the jurisprudence of the ECtHR with respect to long-term migrants and their requests for equal treatment with citizens based on time spent in the country. In Section 4 I identify and discuss the discrepancy between Stopler's normative account of the rights of long-term migrants and that of the ECtHR. I conclude by identifying what is needed for the case law of the Court to be normatively justifiable in the field of long-term migration. Moreover, I show how Stopler's normative account would

\footnotetext{
${ }^{10}$ ECtHR, Khan v Germany, App no 38030/12, 21 September 2016.

${ }^{11}$ ECtHR Osmanoğlu and Kocabaş v Switzerland, App no 29086/12, 10 January 2017; ECtHR, Ebrahimian v France, App no 64846/11, 26 November 2015; ECtHR, SAS v France, App no 43835/11, 1 July 2014; ECtHR, Belkacemi and Ousar v Belgium, App no 37798/13, 11 July 2017; ECtHR, Dakir v Belgium, App no 4619/12, 11 July 2017.

${ }^{12}$ For a comprehensive and critical review of migrant-related case law of the ECtHR, see Dembour (n 5).
} 
benefit from an examination of whether we may still conceive of cases involving long-term migrants as a balancing exercise between their interests and those of the receiving community.

\section{Stopler's Three Stages of Immigration}

Stopler's normative assessment of rights in immigration departs from two central liberal premises that take the existence of national borders as given. First, Stopler holds that rights in immigration are not absolute rights; instead, they are qualified rights the content of which can be clarified by weighing the interests of migrants and the interests of the receiving communities and states. ${ }^{13}$ Second, Stopler holds that a migrant's position in the stages of immigration - ranging from the request for entry (Stage I), the request for citizenship (Stage II) and the migrant's residence in the country of immigration (Stage III) - has a normative impact on how the balancing exercise between the rights of migrants and those of the receiving communities must be carried out. Significantly, the longer a migrant stays in a receiving community, the weaker the interests of the community become to protect its culture against that of the migrant. ${ }^{14}$ Time spent in the recipient country, jus temporis, thus is a significant tool in determining what the migrantreceiving state owes to migrants already present in its territory.

Stopler's normative sliding-scale approach takes it as a given that there is no cosmopolitan right to migrate (leaving aside refugee law) or a right to naturalisation. ${ }^{15}$ She therefore distances herself from the more radical criticisms of the very ideas of national borders, national membership and national identity when she states that 'immigration is not recognized as a universal right under either law or in political theory'. ${ }^{16}$ Instead, the sliding-scale approach offers a compromise between a citizenship-focused liberal theory and a cosmopolitan one: the longer a migrant remains in the receiving country, the weightier and more substantive his or her interests become vis-à-vis the receiving country. An important consequence of this argument is that the long-term stay ought to lead to the migrant's naturalisation and equal treatment with citizens of the recipient state.

As Stopler underlines, the 'long term' migrant's right to remain and naturalise is one that has received wide endorsement from liberal political theorists, irrespective of their commitment to the moral significance of national borders. Walzer sees this as a requirement of democratic theory. A state should extend membership to all those who are part of the life of the society and failing that it would become 'a family with live-in servants' ${ }^{17}$ This view makes a particularly strong case for the protection of long-term temporary guest workers and their families who are not accorded

\footnotetext{
${ }^{13}$ Stopler (n 1) 189.

${ }^{14}$ ibid 190.

${ }^{15}$ Carens (n 5).

${ }^{16}$ Stopler (n 1) 189. But see also Antoine Pécoud and Paul de Guchteneire, 'Migration Without Borders: An Investigation into Free Movement of People', Global Commission on International Migration/UNESCO, Global Migration Perspectives No 27, April 2005, http://www.cestim.it/argomenti/50libera_circolazione/2005-pecoudguchteneire-migration_without_borders.pdf.

${ }^{17}$ Michael Walzer, Spheres of Justice: A Defense of Pluralism and Equality (Basic Books 1983) 52.
} 
long-term resident status or citizenship. Stopler's approach, however, is closer to that of Carens. For Carens, too, the length of time spent in a country itself is normatively significant for migrants to acquire equal rights from a liberal perspective that is truly committed to the equal moral worth of persons, irrespective of their citizenship status. As Carens puts it ' $[t]$ he longer people stay in a society, the stronger their moral claims become. After a while they pass a threshold that entitles them to the same legal status as citizens' ${ }^{18}$ As such, length of time must carry normative significance to generate rights for all types of migrant, including those with an irregular or precarious legal status. ${ }^{19}$ Even if migrants are not naturalised as citizens, the longer their presence in the migrant-receiving community, the stronger their claims are to be treated akin to citizens. Once migrants become citizens their right to equal recognition of their minority culture in the public domain becomes even stronger and the state's interest in protecting the majority culture directly or indirectly becomes weaker.

Liberal theories of migration, however, do not speak in one voice about the normative significance of jus temporis. For some, jus temporis simply offers incentives for non-legal residents to engage in illegal behaviour by overstaying, which the states have a right to suppress under the discretion they enjoy for border control. ${ }^{20}$ For others, the central question is the comparative moral relevance of time spent in the receiving community when pitted against other relevant considerations: namely, the collective interest of the political community to withhold long-term legal status or naturalisation and to deport the long-term migrant. Even Carens, who ultimately advocates open borders, recognises that a state may withhold naturalisation from migrants 'if there is good reason to believe that they will grow up in the state where they were born' ${ }^{21}$ Thus, while liberal political theory directs decision makers to focus on time, it does not give a clear account of how time should figure in complex balancing exercises, creating the risk that it becomes an arbitrary factor in immigration decisions.

\section{Long-Term Migrants and the Case Law of the European Court of HuMAN Rights}

Does the European Court of Human Rights develop the nexus between democratic legitimacy and the recognition of the rights of long-term migrants to be naturalised and remain in the country? Does it treat the length of time as a significant stand-alone test for according citizen-like rights to migrants? In what follows I offer a survey of the case law of the Court on long-term migrants.

\footnotetext{
${ }^{18}$ Carens (n 5) 89. See also Ruth Rubio Marin, Immigration as a Democratic Challenge: Citizenship and Inclusion in Germany and the United States (Cambridge University Press 2000).

${ }^{19}$ Carens (n 5) 150.

${ }^{20}$ Patti Tamara Lenard, 'The Ethics of Deportation in Liberal Democratic States' (2015) 14 European Journal of Political Theory 464, 468.

${ }^{21}$ Carens (n 5) 36.
} 


\subsection{No Absolute Right to Citizenship or Residency, and No Absolute Right not to be EXPELLED}

The case law of the European Court of Human Rights is on a par with the liberal theories of immigration in that it treats rights in immigration as qualified rights in all circumstances. Migrants do not have an absolute right to citizenship ${ }^{22}$ or residency; ${ }^{23}$ nor do they have an absolute right not to be expelled from the country ${ }^{24}$ or a right not to be stripped of their citizenship..$^{25}$

The Court's general approach to citizenship is that there is no such right under the European Convention on Human Rights (ECHR or the Convention) ${ }^{26}$ and that a right to citizenship cannot be directly derived from any of the rights protected in the Convention. ${ }^{27}$ Long-term stay in a country cannot, in and of itself, lead to a right to citizenship. Instead, the Court holds that only when arbitrary denial of citizenship has a serious impact on the private rights of the individual, then it may come within the scope of the Convention. ${ }^{28}$ Arbitrariness in the case law of the Court includes discriminatory application of citizenship laws to individuals. ${ }^{29}$ By the same token, the Court also recognises that migrants can be stripped of their citizenship on the ground of non-compliance with the conditions imposed for acquiring citizenship, for example, by committing fraud or being involved in activities that threaten the public interests of the community as a whole. In both of these instances, the applicant's long-term stay in the country does not on its own compel the state to treat the migrant's citizenship as native citizenship. This has been the case even when the migrant stripped of citizenship faces the risk of statelessness. ${ }^{30}$

Assigning unfettered discretion to states also shapes the Court's approach to rights of residency. In a much-quoted leading judgment - which involved the expulsion from the Netherlands of a Turkish adult who had migrated there when he was 12 years old to join his guest-worker father and was deported after 17 years of stay - the Court set out these general principles with regard to the rights of the receiving state: ${ }^{31}$

The Court reaffirms at the outset that a State is entitled, as a matter of international law and subject to its treaty obligations, to control the entry of aliens into its territory and their residence there. The Convention does not guarantee the right of an alien to enter or to reside in a particular country.

\footnotetext{
${ }^{22}$ ECtHR, Ramadan v Malta, App no 76136/12, 21 June 2016, para 84.

${ }^{23}$ ECtHR, Uner $v$ The Netherlands, App no 46410/99, 18 October 2006.

${ }^{24}$ Khan (n 10).

${ }^{25}$ Ramadan (n 22); K2 (n 8)

${ }^{26}$ European Convention for the Protection of Human Rights and Fundamental Freedoms (entered into force 3 September 1953) 213 UNTS 221 (ECHR).

${ }^{27}$ ECtHR, Karassev v Finland, App no 31414/96, 12 January 1999, para 1(b).

${ }_{28}$ ibid; ECtHR, Savoia and Bounegru v Italy, App no 8407/05, 11 July 2006.

${ }^{29}$ ECtHR, Genovese v Malta, App no 53124/09, 11 October 2011. The Court found that not granting citizenship to an illegitimate child of a Maltese citizen was discriminatory.

${ }^{30}$ Ramadan (n 22). See also the dissenting opinion of Judge Pinto de Albuquerque.

${ }^{31}$ Üner (n 23) para 54. See also Jeunesse (n 9) para 100.
} 
Unlike the liberal theories of immigration, which show concern for long-term migrants, the ECtHR does not differentiate a priori between short- and long-term migrants in discussing rights of residency. For the Court, granting residency is a domain of sovereign states in its totality. In Uner, the Court underlined this principle when it stated: 'These principles apply regardless of whether an alien entered the host country as an adult or at a very young age, or was perhaps even born there'. ${ }^{32}$

Furthermore, the Court also finds that there are a priori categorical differences between citizens and migrants, despite the birth or the long-term stay of the latter in the receiving country, when it comes to decisions relating to expulsion. In Üner, the Court insisted on this a priori categorical difference in strong terms: ${ }^{33}$

The Court considers nevertheless that, even if a non-national holds a very strong residence status and has attained a high degree of integration, his or her position cannot be equated with that of a national when it comes to the above-mentioned power of the Contracting States to expel aliens.

The Court does, however, differentiate between 'settled migrants' (defining 'settled' as those migrants with a formal legal status in a country) and migrants whose legal status is pending. ${ }^{34}$ According to the Court, settled migrants enjoy the right to family life in the receiving country and any interference with their right to family life must be necessary and proportionate in a democratic society. ${ }^{35}$ The term 'settled migrants', however, is not consistently used as a synonym for long-term migrants. The Court does not always adopt a clear position on whether the length of stay in the country can trigger rights despite the lack of legal status for the migrant. ${ }^{36}$ In cases where a migrant is long-term but not settled legally, the Court is less likely to find a breach of the migrant's right to private and family life because the competing interests, in these instances, tend to carry greater weight. ${ }^{37}$

This principled stance of the ECtHR in differentiating between long-term migrants and citizens, as well as between settled long-term migrants and unsettled long-term migrants, goes

\footnotetext{
${ }^{32}$ Üner (n 23) para 55.

${ }^{33}$ ibid para 56.

${ }^{34}$ Jeunesse (n 9) para 104. See also Üner (n 23) para 59: 'It must be accepted that the totality of social ties between settled migrants and the community in which they are living constitute part of the concept of "private life" within the meaning of Article 8. Regardless of the existence or otherwise of a "family life", therefore, the Court considers that the expulsion of a settled migrant constitutes interference with his or her right to respect for private life'. Legal status is also a significant aspect of European Union (EU) law in assigning rights to long-term migrants: Council Directive 2003/109/EC of 25 November 2003 Concerning the Status of Third-Country Nationals who are Long-Term Residents [2004] OJ L 16.

${ }^{35}$ ECtHR, Boultif v Switzerland, App no 54273/00, 2 August 2001; Üner (n 23); ECtHR, Savasci v Germany, App no 45971/08, 19 March 2013; ECtHR, Maslov v Austria, App no 1638/03, 23 June 2008; ECtHR, Udeh v Switzerland, App no 12020/09, 16 April 2013; ECtHR, Omojudi v United Kingdom, App. no 1820/08, 24 February 2010.

${ }^{36}$ cf Jeunesse (n 9), where 'settled' is used exclusively to refer to legal status; also ECtHR, Slivenko v Latvia, App no 48321/99, 9 October 2003, where the Court places emphasis on the long-term presence of the applicants in Latvia.

${ }^{37}$ Jeunesse (n 9) para 105.
} 
against the approach of categorising migrants based merely on the time they have spent in the receiving country. Unlike the sliding-scale approach, the Court's starting point is the primacy of a state's right to govern its immigration policy by assigning different types of legal status to migrants. There is thus no general theory of human rights and how the human rights of the individual may be best protected in a liberal democratic society to inform the migrant-related case law of the ECtHR.

\subsection{Length of Stay: Not a Stand-alone Mark of Rights in Immigration}

If a long-term migrant's length of stay does not receive normative significance as a matter of principle, how does it figure in the balancing exercises that the ECtHR undertakes when it considers that a state's migration policy interferes with one of the protected rights in the Convention?

At the centre of the Court's approach to rights in migration is the right to private and family life, which for the Court is a multifaceted right. It covers the family ties and other relationships of migrants in the receiving country, ${ }^{38}$ as well as their level of social integration in the society. ${ }^{39}$ Despite this broad definition of the right to private and family life, under the ECHR migrants do not have a prima facie right to continue to enjoy these rights in the receiving state. ${ }^{40}$ This flows from the Court's acceptance that migrants do not automatically qualify for citizenship status or citizen-like treatment based on their length of stay or relationships in the receiving country. Immigration policy, such as refusal of legal residency or expulsion from the country, can be carried out as long as these decisions do not come at a high cost to the private and family life of the migrant and they are a proportionate response to the aims pursued by such policies.

In the case law of the European Court of Human Rights, states assert their margin of appreciation in the field of immigration policy with respect to long-term migrants when they hold that the prevention of crime and disorder, national security or public order are at stake. ${ }^{41}$ The prevention of crime and disorder cases concern the 'misbehaving' long-term migrants in receiving communities. In these cases, states often seek to deport long-term migrants, even though they may have spent a significant part of their lives in the migrant-receiving states with no access to naturalisation because of the criminal offences they have committed.

In such a case, the Court asks the state to demonstrate whether it has struck a fair balance between the interests of the receiving community and the interests of the long-term migrant to enjoy a private and family life in that state. In what is known as the 'Boultif criteria', the Court asks states to consider a range of concerns in striking a fair balance. These can be summarised broadly around: (i) the length of stay; (ii) the seriousness of the migrant's criminal

\footnotetext{
${ }^{38}$ ECtHR, Emre v Switzerland, App no 42034/04, 22 May 2008.

${ }^{39}$ Slivenko (n 36); Üner (n 23).

${ }^{40}$ ECtHR, Trabelsi v Germany, App no 41548/06, 13 October 2011; ECtHR, Berisha v. Switzerland, App. no 948/12, 20 January 2014.

${ }^{41}$ These are the legitimate aims for restriction of the rights under art 8 of the ECHR (n 26).
} 
convictions, conduct since conviction and the risks of reoffending; and (iii) the impact of removal on family relationships, especially on children. ${ }^{42}$

These criteria overlap and intersect with one another and are therefore highly fluid. While length of stay may be significant, a migrant who commits serious offences and has no social ties - and hence is not well-integrated into the society - may still be deported. ${ }^{43}$ If criminal convictions are not deemed too serious (in terms of number of offences and post-conviction behaviour), and the migrant has remained in the country for a long time and has children, fair balance may require a legalised right to remain in the country despite the criminal convictions. ${ }^{44}$ If the conviction is serious, and even if the long-term migrant is mentally ill and has no meaningful social ties in his or her native country, the Court may view the deportation as part of a fair balance. $^{45}$

It was in Üner that the Court aimed to develop a more principled approach to the length of stay as a normatively significant criterion for the deportation of migrants, although even in this case, the Court maintained that this was merely one consideration out of many in decisions concerning the treatment of long-term migrants. In this case the Court held that: ${ }^{46}$

[A]lthough the applicant in Boultif was already an adult when he entered Switzerland, the Court has held the 'Boultif criteria' to apply all the more so (à plus forte raison) to cases concerning applicants who were born in the host country or who moved there at an early age (see Mokrani v. France, no. $52206 / 99$, § 31, 15 July 2003). Indeed, the rationale behind making the duration of a person's stay in the host country one of the elements to be taken into account lies in the assumption that the longer a person has been residing in a particular country, the stronger his or her ties with that country and the weaker the ties with the country of his or her nationality will be. Seen against that background, it is self-evident that the Court will have regard to the special situation of aliens who have spent most, if not all, their childhood in the host country, were brought up there and received their education there.

\footnotetext{
${ }^{42}$ In Boultif (n 35) the Court set out detailed criteria, which include the nature and seriousness of the offence committed by the applicant; the length of the applicant's stay in the country from which he or she is to be expelled; the time elapsed since the offence was committed and the applicant's conduct during that period; the nationalities of the various persons concerned; the applicant's family situation, such as the length of the marriage, and other factors expressing the effectiveness of a couple's family life; if there is a spouse, whether the spouse knew about the offence at the time when he or she entered into the family relationship; whether there are children of the marriage, and if so their age; and the seriousness of the difficulties that the spouse is likely to encounter in the country to which the applicant is to be expelled. See also Üner (n 23) para 58.

${ }^{43}$ Trabelsi (n 40). In this case the applicant was born in Germany in 1983 and at the time of the decision had been living there for 28 years.

${ }^{44}$ In Omojudi (n 35) the Court took into account the nature and seriousness of the offence and the migrant's family, social and cultural ties with the host and the citizenship state, in conjunction with 26 years of residence in the UK to find the deportation order disproportionate. In Udeh (n 35) paras 52-54, the Court recognised seven and a half years as a significant amount of time in terms of length of stay.

${ }^{45}$ Khan (n 10).

${ }^{46} \ddot{U}$ ner (n 23) para 58. Despite the importance of the principles set out, the Court found no breach of art 8 of the ECHR (n 26). While it accepted that the applicant had strong ties with the Netherlands, he had weak family relationships with his partner and son. The Court held that returning the applicant to Turkey, while it may not be easy, was not unreasonable given the seriousness of his criminal convictions.
} 
In the case of Jeunesse $v$ The Netherlands ${ }^{47}$ the Court extended the duty to strike a fair balance to the domain of the rights of long-term migrants who have a non-settled (irregular) migration status. The applicant, who was a national of Suriname, had a husband with Dutch nationality as well as three children born in the Netherlands who also all had Dutch nationality. Her attempts to gain a residence permit were consistently refused by authorities on the ground of her failure to comply with national immigration rules. ${ }^{48}$ The Court in this case paid due regard to multiple factors such as her status as the primary caregiver for her children, her level of integration into the society, the contribution of the actions of the government to her long-term stay and the absence of a criminal record. Instead of developing the normative significance of long-term migration, however, the Court found the facts of the case exceptional in deciding that the state had failed to strike a fair balance. ${ }^{49}$

\subsection{Can Time Alone Trigger Claims of Discriminatory Treatment?}

The discrimination clause in the European Convention on Human Rights (Article 14) is well known for its dependency on other rights in the Convention. ${ }^{50}$ A long-term migrant pursuing a case under Article 14 must show that one of the rights protected in the Convention is involved and in the context of this right the migrant is subject to discriminatory treatment. As shown in the previous section, making discrimination arguments for long-term irregular migrants faces an insurmountable obstacle, as such migrants, prima facie, do not enjoy, for example, a family life in the receiving state that may protect them from deportation or allow them to receive regularised status. The case law of the European Court of Human Rights, however, recognised that legally resident long-term migrants can have legitimate discrimination claims with respect to their enjoyment of possessions (pensions and benefits) and enjoyment of their right to private and family life.

The principal case that recognised that long-term migrants must not be discriminated against based on their nationality is Gaygusuz v Austria, decided in $1996 .{ }^{51}$ In this case, paying due regard to the long-term legal migrant status of Gaygusuz, the Court found that withholding social security benefits from him based on his nationality was a violation of the prohibition against discrimination in conjunction with the right to enjoyment of possessions. The Court found that an

\footnotetext{
${ }^{47}$ Jeunesse (n 9).

${ }^{48}$ She had arrived in the Netherlands on a short-term tourist visa and remained unlawfully in the country after her visa expired.

${ }^{49}$ Jeunesse (n 9).

${ }^{50}$ Protocol No 12 to the 1950 European Convention for the Protection of Human Rights and Fundamental Freedoms, (ETS No 177), also gives the principle of non-discrimination an independent status. To date, however, only 20 states have ratified Protocol 12. On the scope of art 14 and Protocol 12 see Oddný Mjöll Arnardóttir, 'Discrimination as a Magnifying Lens: Scope and Ambit under Article 14 and Protocol 12' in Eva Brems and Janneke Gerards (eds), Shaping Rights in the ECHR: The Role of the European Court of Human Rights in Determining the Scope of Human Rights (Cambridge University Press 2013) 330.

${ }^{51}$ ECtHR, Gaygusuz v Austria, App no 17371/90, 16 September 1996. See also Marie-Bénédicte Dembour, 'Gaygusuz Revisited: The Limits of the European Court of Human Rights' Equality Agenda' (2012) 12 Human Rights Law Review 689.
} 
Austrian citizen and Gaygusuz were like-for-like, in the sense that they both contributed to social security funds and must therefore be treated in the same way. In this case, the Court made what is still regarded as a bold statement in stating that 'very weighty reasons were required to justify discrimination' between legally settled long-term migrants and citizens. ${ }^{52}$ In subsequent cases, the Court has continued to entertain discrimination claims, also in conjunction with the long-term migrant's right to family life, holding, for example, that denial of child benefits to legal long-term migrants because their residence permits were time-limited was discriminatory. ${ }^{53}$

It was the Anakomba Yula case against Belgium in 2009 that allowed the Court to elucidate a more principled stance with respect to discriminatory practices against irregular long-term migrants. The government, in this case, argued that the irregular status of a migrant is an objective ground for discrimination in the context of requests for judicial assistance in paternity proceedings. ${ }^{54}$ The Court rejected this argument and stated that only 'very weighty reasons could justify a difference of treatment between the applicant who did not have a residence permit and people who did have such a permit'. ${ }^{55}$ In reaching this conclusion, however, the Court used fact-specific arguments that the applicant was a 'quasi-regular migrant'; thus it fell shy of developing a normative stance that tied equality claims with the time spent by the migrant in the country and not the legal status of the migrant. ${ }^{56}$

The case of Bah v United Kingdom in 2011 put to the test whether the 'very weighty reasons' concept meant a special type of balancing exercise in discrimination cases involving long-term migrants. ${ }^{57}$ The applicant in this case was denied equal treatment in accessing priority social housing because, even though she was a long-term migrant with regular residency status, her juvenile son, who travelled from Sierra Leone to join her, was in the UK under immigration control orders. The housing authorities refused to put her on the priority social housing list on the basis of the immigration status of her son. The UK Equality and Human Rights Commission argued, in a third party intervention in the case, that this was a form of structural discrimination as the UK housing policy was based on a needs assessment and parents with children enjoyed priority under the scheme regardless of the status of the child. ${ }^{58}$ The ECtHR, however, held that the government had a legitimate objective interest - the fair distribution of social housing - and enjoyed a wide margin of discretion in this area. ${ }^{59}$ In this respect, the government's prerogative to organise and allocate limited resources in the area of social policy was given the upper hand at the expense of the 'very weighty reasons' doctrine. The Court found that: ${ }^{60}$

\footnotetext{
${ }^{52}$ Gaygusuz, ibid para 42.

${ }^{53}$ ECtHR, Niedzwiecki v Germany, App no 58453/00, 25 October 2005; ECtHR, Okpisz v Germany, App no 59140/00, 25 October 2005.

${ }^{54}$ ECtHR, Anakomba Yula v Belgium, App no 45413/07, 10 March 2009, para 29.

55 ibid para 37.

56 ibid para 38 .

${ }^{57}$ ECtHR, Bah v United Kingdom, App no 56328/07, 27 September 2011. See also the discussion of these cases in Dembour (n 5).

${ }_{58}^{58}$ Bah, ibid paras 33-34.

${ }^{59}$ ibid para 49.

${ }^{60}$ ibid para 52.
} 
[The] differential treatment to which the applicant was subjected was reasonably and objectively justified by the need to allocate, as fairly as possible, the scarce stock of social housing available in the United Kingdom and the legitimacy, in so allocating, of having regard to the immigration status of those who are in need of housing.

The time spent by a legal migrant in the receiving country thus was trumped by the prior needs of the citizens to access local housing.

\section{Discrepancies Between Strasbourg Case Law and Stopler’s Normative FramewOrK}

The preceding analysis shows that while the length of time spent by a migrant in a country receives a normative place in the case law of the European Court of Human Rights, more time spent does not generate more rights or equal rights with citizens. Instead, the length of stay is a criterion that is taken into account together with other criteria, in particular, in conjunction with the strength of personal and social ties that a migrant is able to develop in the time that he or she spends in the receiving country, the legal nature of the length of time spent, and the recognition that citizens enjoy priority over long-term migrants in the distribution of resources. The Court, therefore, does not see jus temporis on a sliding scale, but in competition with other considerations. ${ }^{61}$ This approach is likely to favour those who arrived in a country as a child, those who have children whose other parent is a citizen, those who can speak the language of the country and those who indisputably lost their social ties with the country from which they came. Undoubtedly, the Court also looks more favourably upon legally resident long-term migrants than irregular migrants, despite the significant amount of time the latter may have spent in a country. ${ }^{62}$ None of these considerations taken together, however, can trump the weighty public interests of states, which allow them to deny residency and expel migrants or to refuse to distribute social benefits based on migration status.

Why is there a discrepancy between the case law and the liberal normative theory of jus temporis? We may consider two arguments to explain this. The first argument focuses on the logic of European human rights law and the way in which legal stock shapes how the ECtHR views longterm migrants. The second focuses on the liberal theory itself and asks whether making rights in immigration part of a balancing exercise, while also assigning heightened importance to the time spent in the receiving state, offers a sound applied normative theory.

\footnotetext{
${ }^{61}$ On the distinctions between jus temporis and jus nexis, see Paulina Ochoa Espejo, 'Taking Place Seriously: Territorial Presence and the Rights of Immigrants' (2016) 24 The Journal of Political Philosophy 67.

${ }^{62}$ ECtHR, Abuhmaid v Ukraine, App no 31183/13, 12 January 2017. The applicant had lived in the Ukraine for over 20 years.
} 


\subsection{THE Limits OF THE LAW}

In European human rights law, the articles in the European Convention on Human Rights under which legal argumentation can be made matter significantly. Given the absence in the Convention of legally established hard norms on the rights of migrants, the case law on such rights has focused exclusively on their right to private and family life and the right to nondiscrimination. While the focus on the right to private and family life humanises the migrant, it also places the burden of legal integration on the migrant, who must show that she has legal status as well as a vibrant family and social life in the receiving country. The migrant also must show that her right to private or family life is not 'transportable' elsewhere. ${ }^{63}$ In most respects there is a heavy burden on the migrant to prove legal and social integration irrespective of the time spent in the receiving country. What is more, this approach does not take into account the negative effects that precarious legal arrangements or lack of citizenship have in developing a vibrant private life.

The necessity of proving the existence of a legally and socially integrated private and family life in the receiving country distracts from the neutrality of the jus temporis approach. This approach proposes time spent in the receiving country as a proxy for the existence of social ties and integration, and places the burden of legal integration on the state and not solely on the migrant. Under the temporal requirement, a migrant does not additionally have to show that she has become a successfully integrated person. The time requirement, which the Council of Europe Committee of Ministers recommends as 'at least five years', ${ }^{64}$ is all that is required. The social integration model carries the risk of creating different classes of migrant without paying adequate attention to the opportunities available to migrants for such integration.

The social and legal integration bias of the case law aside, the European Court of Human Rights further sees states as enjoying a wide margin of appreciation when it comes to migration. ${ }^{65}$ This margin of appreciation is both explicit and implicit, and is deeply entrenched in the general approach to long-term migrants in the case law of the Court. The Court has made some inroads into placing constraints on deporting migrants, as discussed in Section 3. These criteria, however, are relative to one another, and lead to casuistic reading rather than principled reasoning concerning long-term migrants. The case law is not about long-term migrants, but $a$ long-term migrant. Cases turn on the facts, which means that the long-term status of a migrant has factual significance, but not normative significance. What is more, as long as domestic courts pay due regard to the long list of criteria that the Court has identified, the Court carries out a lenient review of the facts in the cases it adjudicates. ${ }^{66}$

${ }^{63}$ Maslov (n 35) para 63.

${ }^{64}$ Council of Europe, Recommendation Rec(2000)15 concerning the Security of Long-Term Migrants, 13 September 2000.

${ }^{65}$ Ebrahimian (n 11); SAS (n 11); Bah (n 57).

${ }^{66}$ Abuhmaid (n 62). On the lenient review of domestic court decisions of the ECtHR see Başak Çalı, 'Towards a Responsible Domestic Courts Doctrine? The European Court of Human Rights and the Variable Standard of Judicial Review of Domestic Courts' in Oddný Mjöll Arnardóttir and Antoine Buyse (eds), Shifting Centres of 
A central weakness of the Court's case law on assigning normative significance to long-term migration is its association of long-term migrants with long-term legally resident migrants. The Court, for example, holds that an illegal migrant cannot come within the protection of the right to family life on the territory of the receiving state if she and her relations had knowledge of the illegality when the family ties were formed.$^{67}$ The private and family life of an irregular or illegal migrant, therefore, is suspect, despite the length of time the person stays in another country. This assumption also goes against assigning normative significance to time. It further reifies the distinction between legal long-term migrants and illegal long-term migrants and therefore strengthens the margin of appreciation of states. It is, after all, states who decide on the legal status of migrants on their territory.

\subsection{Limits of Time as a Feature of a Liberal Theory based on Balancing}

The previous sections have shown that the liberal argument for jus temporis having a stand-alone normative significance in theories of migration has not been well received by the case law of the European Court of Human Rights. Time is never considered in isolation in its case law, and it receives even less consideration for irregular or illegal migrants. Is this merely as a result of the limits of human rights law and its statist bias, ${ }^{68}$ in particular in the field of migration? Could there also be shortcomings in the liberal normative framework itself?

The liberal approach to migration, of which Stopler's work forms part, is built on two central premises. First, the theory starts with the assumption that the rights in migration are a matter of balancing between the interests of the migrant and the interests of the receiving community. This means that the moral significance of borders and national membership are taken for granted in approaching migration. Second, in the balancing act, time spent in the receiving country must work in favour of the migrant's naturalisation and her full inclusion into the society. The second aspect of the theory aims to assert that liberal theory, as applied within national borders, is nevertheless sensitive to the equal moral worth of individuals. Time spent in the country is a neutral proxy for the social integration of migrants into a national society and thus legitimises their request to be treated as citizens. Focusing on time and not social integration further respects the cultural identity of the migrant and does not place the burden of integration solely on the migrant herself.

What the analysis of Strasbourg case law shows, however, is that time spent in the country does not have a stand-alone weighty normative status as a matter of European human rights

Gravity in Human Rights Protection: Rethinking Relations Between the ECHR, EU, and National Legal Orders (Routledge 2016) 144.

${ }^{67}$ Jeunesse ( $\mathrm{n} 9$ ). When the Court recognises that the long-term irregular migrant (a mother of three children who are all Dutch citizens) has a family life, it is very cautious to underline that this is an exceptional situation.

${ }^{68}$ Dembour (n 5). On the analysis of discrepancies between normative theory and human rights law as a result of the latter's statist bias, see also Saladin Meckled-Garcia and Başak Çalı, 'Lost in Translation: The Human Rights Ideal and International Human Rights Law' in Saladin Meckled-Garcia and Başak Çalı (eds), The Legalization of Human Rights, Multidisciplinary Perspectives (Routledge 2006) 11. 
law. Its importance does not increase in the case law based on the length of time a migrant is present in the country. European liberal democratic states continue to argue, and the ECtHR tends to agree, that how and under what status the migrant spends that time matter more than the length of time itself in balancing the interests of migrants and their receiving communities, as evidenced by the cases discussed above. ${ }^{69}$ Could liberal normative theory do more to bolster the centrality of jus temporis, while holding on to the idea that the state must play a central role in controlling migration in the interests of its citizenship?

One way forward with the weak traction of jus temporis in human rights law is to insist that after the passage of a certain amount of time (say, ten years) time spent must gain lexical priority over other concerns. In other words, it may no longer be subject to being balanced with the interests of migrant-receiving communities. Among liberal theorists, this is the position most strongly advocated by Carens. ${ }^{70}$ In this account, the passage of time not only increases the interests of migrants, but solidifies their interests and triggers absolute duties for liberal democratic states. These duties concern equal treatment of long-term migrants with citizens in all spheres of law and policy, including the duty not to deport them. It is also argued that the lexical priority accorded to time spent must apply to both legal and irregular migrants.

A second option towards moving forward would be to expand the range of normative considerations that are included in the balancing act, so that the balancing act does not produce indeterminate outcomes for long-term migrants based on the facts of each and every case, but that it operates to defend the rights of long-term migrants qua long-term migrants. This can be done, for example, by asserting that time is not only a trigger of rights for migrants, but also of duties by the state. This requires asking not simply what the migrant has done in that time, but also whether the liberal state has met particular requirements for trying to integrate migrants. This would enable the Court to include in its examination of the cases whether there are obstacles in obtaining citizenship (say, after five years) and whether the state has provided adequate opportunities for irregular migrants to regularise their status and to apply for citizenship. Whether a state lacks an enabling environment for regularising or naturalising migrants then would become part of the balancing act in considering the right-to-remain cases of migrants. In other words, liberal theories of rights in migration may benefit from focusing on impediments that prevent jus temporis doing its normative work and highlighting more that states owe duties of inclusion to long-term migrants. The re-centring of the focus of time towards state duties would garner support both from theories of "fair terms of integration" ${ }^{71}$ and from commitment to democratic inclusion.

\footnotetext{
${ }^{69} \mathrm{cf}$ Omojudi (n 35) paras 45-46. EU law also reflects this approach: see, in particular, the EU Directive 2003/109/ EC (n 34).

${ }^{70}$ Carens (n 5).

${ }^{71}$ Stopler (n 1) 192.
} 


\section{CONCLUSION}

In this article, departing from Stopler's liberal normative framework of rights in migration and her emphasis on the significance of jus temporis to demand more rights for migrants in the receiving communities, I have surveyed how jus temporis figures in the case law of the European Court of Human Rights. I have argued that jus temporis is present in the case law of the Court, but it lacks a normative significance in striking a fair balance between the rights of migrants and the receiving communities. I further held that the absence of a principled use of jus temporis in the case law of the Court is not as a result of a general statist bias, but is also because of the ambiguous guidance offered by liberal theory about how time should figure in balancing the rights of migrants and the receiving communities. The Court needs further guidance from liberal theories of migration about how normatively to defend jus temporis as a weighty normative concern. For critics of liberal theory of migration, this is a dead end. Balancing exclusion with inclusion has deeply indeterminate qualities with built-in biases in favour of exclusion, national borders and national membership. ${ }^{72}$ At a time when, in liberal democracies across Europe, hostility to open migration policies and migrants in general is on the rise, liberal normative theory must do more to defend the rights of long-term migrants, who are stuck in the maze of domestic immigration laws. This will have the potential to improve the current case law on long-term migrants at the ECtHR, which currently focuses on the rights of individual migrants on a case-by-case basis, rather than a normative principled approach to the rights of long-term migrants in a liberal democratic regime.

\footnotetext{
${ }^{72}$ Dembour (n 51).
} 


\title{
Rights in Immigration: The Veil as a Test Case
}

\author{
Gila Stopler*
}

Immigration often involves the migration of people of specific cultural and religious background to countries in which the predominant cultural and religious background is quite different. This may result in attempts by receiving countries to restrict the new immigrants' cultural and religious practices. The Article uses the debate surrounding the wearing of the veil in Europe as a test case for the way in which recognition rights may be affected by the process of immigration. First, the Article maintains that the balance of rights and interests involved in conflicts over immigrants' rights changes along the process of immigration, and divides this process into three stages - the entry application, the application for citizenship, and the life as an immigrant in the receiving country. Subsequently, it lays out the conflicting rights and interests involved in the veil controversy - the conflict between immigrant and local cultures; the conflict between immigrants' religious liberty and state interests such as maintaining religious neutrality/laïcité, and protecting from the perceived threat of radical political Islam; the conflicting claims regarding the effects of veiling on women's equality. Finally, the Article analyzes each of these conflicts along the three stages of immigration and offers an assessment of the validity of the conflicting claims surrounding the veil in Europe on the basis of this analysis, claiming that the restrictions on wearing the veil in the public sphere are not justified, but that a much narrower restriction pertaining to some instances of the wearing of the full face burqa can be justified.

\section{INTRODUCTION}

Immigration often involves the migration of people of specific cultural and religious background to countries in which the predominant cultural and religious background is quite different. Cultural and religious practices of the new immigrants may seem strange and, at times, even offensive to the population of the receiving countries; the authorities may use various measures to try to impede public expressions of immigrants' practices and customs. In Europe over the recent years, one of the most

• Lecturer, Academic Center of Law \& Business, Ramat Gan, Israel. This Article was written as part of my participation in a working group on "Immigration and Human Rights" sponsored by the Minerva Center for Human Rights at the Hebrew University. I would like to thank the Minerva Center for its generous support for this project. I would also like to thank the participants of the international conference on "Human Rights and Justice in Immigration: National and International Perspectives," organized by the Minerva Center (Jerusalem, May 2009) for their useful comments, and the Israel Law Review editors and the anonymous reviewer for their excellent comments and editorial work." 
controversial practices in this context has been Muslim veiling, which has stirred much public debate as well as triggered restrictive legal measures.

This Article examines this controversy as it has emerged in such countries as France and Germany and offers insight into some of the processes that can transpire when immigrants from mostly traditional and illiberal communities immigrate into Western liberal societies. Muslim immigration into Europe seems a particularly apt and compelling case in this respect. Europe's Muslim population is almost exclusively composed of relatively recent immigrants and their children. The majority of native-born Europeans tends to share Christian-secular cultural identities that significantly differ from the immigrant identities and make the conflict between the two communities particularly acute. ' Another important factor that intensifies the conflict in the European context is that most, if not all, European countries do not perceive themselves as immigration countries and, consequently, are reluctant to adapt to the changes borne by immigration. ${ }^{2}$ This is further exacerbated by the large Muslim immigrant communities in Europe. ${ }^{3}$

The reactions of European countries to the Muslim practice of veiling ${ }^{4}$ have not been identical. For example, some countries have only placed a ban on public school teachers wearing the veil; in other countries, public school students are also prohibited from wearing it. Yet, other countries have not banned the practice at all. ${ }^{5}$ Other possible responses to the veil include denying female immigrants long-term entry visas or even rejecting their citizenship applications due to the fact that they wear it, or a more conservative, burqa. The differences in the reactions of European countries to the veil stem from the diversity of understandings and applications of concepts such as religious liberty, state neutrality, and women's equality in these different countries. ${ }^{6}$

1 Jose Casanova, Religion, European Secular Identities, and European Integration 1 (July 29, 2004), available at http://www.eurozine.com/articles/2004-07-29-casanova-en.html\#. "Secular" and "Christian" cultural identities are intertwined in complex and rarely verbalized modes among most Europeans."

${ }^{2}$ Birgit Sauer, Conflicts over Values: The Issue of Muslim Headscarves in Europe, 2-3 http://birgitsauer.org/onlinetexte/Conflicts\%20over\%20values-1.pdf (last visited Apr. 11, 2010).

${ }^{3}$ While exact number are difficult to establish, due to problems with the census and under compilation of these figures, in 2004 Muslims comprised more than $8 \%$ of the French population; in Germany, they comprised 3.6\%; in the Netherlands 5.8\%; and in Switzerland $4.2 \%$ of the population. See Muslims in Europe: Country Guide, BBC News, Dec. 25, 2003, available at http://news.bbc. co.uk/2/hi/europe/4385768.stm.

${ }^{4}$ My usage of "veil" refers to the Islamic scarf (hijab) that covers the hair and sometimes the shoulders, and "burqa" to the full-length garment that covers the entire body, including the head and face, and is also referred to as the "niqab."

${ }^{5}$ Sawitri Saharso, Headscarves: A Comparison of Public Thought and Public Policy in Germany and the Netherlands, 10 Critical Rev. InT'L Soc. \& POL. Phil. 513 (2007).

${ }^{6}$ Id. at $527-28$. 
In this Article, I examine the restrictive measures and approaches to veiling and suggest a normative framework for assessing their validity.

Immigration as a process can impact upon human rights in each of the different dimensions of justice: recognition, redistribution, and political participation. ${ }^{7}$ A receiving country may refuse to accommodate the cultural practices of immigrants; immigrants may be relegated to low-skilled, low-wage jobs; and their political participation may be restricted at both the national and local levels. This Article focuses on the impact on their recognition rights that immigrants might experience over the course of the immigration process into a country that is culturally different, and proposes a structured framework for examining whether the outcomes are compatible with principles of justice. Immigration to a culturally different country is fraught with adversities for both the immigrants and the receiving community. While the immigrants complain that their rights to religious freedom, equality, and culture are being violated, the receiving communities feel that their rights, as well as their way of life, are at peril, and authorities take at times excessive, at times insufficient, measures to try to neutralize this perceived threat. Thus, restrictions on veiling should not be understood as a mere prohibition against wearing a specific article of clothing; rather, it is a symbol of the difficulties of accepting different cultural and religious practices, especially those that are perceived as embodying questionable values and norms. ${ }^{8}$

Mutual accusations between the receiving community and the immigrant communities have arisen regarding the violation of their respective rights with each side attempting to substantiate its claims with conflicting legal and theoretical arguments on relevant rights and interests. To make order of these claims and set them in the context of the immigration process, this Article proposes dividing the immigration process into three separate stages (Stages I, II, \& III) and carefully assessing the relevant cultural rights, fundamental rights, and state interests involved at each of these stages. Thus, within this framework, Part I asserts that a structured discussion of how immigration affects human rights in general, and the right to wear the veil in particular, must distinguish between: (Stage I), the request for entry into the receiving country; (Stage II), the request for citizenship; and (Stage III), residence in the country of immigration-beginning with entry into the country and even continuing well beyond citizenship and full integration

${ }^{7}$ On the three dimensions of justice - recognition, redistribution and political participation-in the context of multicultural claims, see Gila Stopler, Contextualizing Multiculturalism -A Three Dimensional Examination of Multicultural Claims, 1 L. \& Eтнісs Hum. RTs. 309 (2007).

${ }^{8}$ It is important to recall that different types of veils bear different meanings and that the most common form - a scarf covering the hair and neck - in itself has varied and complex connotations for Muslim women. See infra note 98 and accompanying text. 
into the receiving society. I argue that the importance of this distinction lies with the differential treatment of the rights and interests implicated and the way that they should be balanced against one another in each stage. For instance, the right to culture of an immigrant residing in the country of immigration (Stage III) should be assessed differently from the parallel right of someone seeking an entry visa (Stage I) relative to the right to culture of the receiving community.

Within the context of immigration, the central rights that are attached to the veiling issue are the cultural rights of immigrants and the receiving community, immigrants' right to religious freedom, and the equality of women both in the immigrant and the receiving community. These rights might clash with one another, as well as with various state interests, such as the interest in preserving the state's religious neutrality. Accordingly, following Part I, the Article distinguishes between three sets of conflicts and analyzes each one separately, ${ }^{9}$ with the aim of constructing a framework for assessing conflicts of recognition in the specific context of immigration. Part II discusses the conflict between the cultural rights of immigrants and those of the receiving community. It defines the parameters of the right to culture in the context of immigration and discusses whether immigrants have such a right, and if so, what is its appropriate scope. The section continues by determining whether the receiving community has a parallel right to culture and what are the justifiable measures that may be used to protect that right.

Part III then addresses the conflict between immigrants' right to religious liberty and the state's interests such as secularism and state neutrality in religion. Theoretically, because the right to religious liberty is a fundamental human right, it should not be affected by the context of immigration. However, constraints can be placed even on a fundamental human right in order to protect important state interests. The immigration into Europe of veiled Muslim women has sparked a clash between their right to religious liberty and the interests of states that did not have to contend with this practice prior to their immigration. The manner the courts adjudicate this issue is discussed and evaluated within the framework of this section.

Part IV proceeds to discuss the conflicting sets of claims that have been grounded in women's equality relating to the rights of immigrant women and of women in the receiving community and the state's interest in guaranteeing women's equality. Finally, Part V draws upon various elements of the discussion and considers the appropriate approach to the veiling practice in each of the three stages of immigration.

\footnotetext{
${ }^{9}$ It is important to stress that because the purpose of this Article is to propose a framework for assessing conflicts of recognition in immigration, the analysis of the conflicts is restricted to this context and will not extend to areas such as national minorities or indigenous people.
} 
The major objective of this Article is to establish and apply a critical frameworkbased upon the three stage process of immigration - for examining and assessing the veiling controversy in the context of immigration from the normative perspective of liberal theory. I argue that from the perspective of liberal theory the fitting solution to the veil controversy specifically, and to similar recognition conflicts in the context of immigration generally, is a "thin" multiculturalism approach toward immigrant communities. ${ }^{10}$ Application of this approach requires that the state accommodate those cultural and religious practices of immigrant communities that do not violate basic human rights, while at the same time mandates the acceptance and respect for liberal values by immigrants. I argue that such an approach is particularly suited to immigration because immigrants are entering an established political and cultural community that should not be expected to compromise its core values, particularly respect for universal basic human rights.

\section{The Three Stages of Immigration}

When considering the process of immigration, it is important to first identify the beginning of the process, the path of its progression, and its culmination. For the purposes of this Article, the starting point can be reasonably regarded as submission of an entry visa application (Stage I). The second focal point of the immigration process is application for citizenship in the receiving country (Stage II). However, while the grant of citizenship is not an inevitable outcome, even its receipt does not necessarily represent the end of the immigration process. Oftentimes, citizenship does not confer full acceptance of the immigrant by the receiving community or conversely, the immigrant's full acceptance of the receiving community. Thus, Stage III of immigration might continue long after naturalization (or denial of citizenship) and perhaps extend to second and third generations of immigrants. Perhaps not surprisingly, the more the receiving country denies being a country of immigration and the less effort it makes to integrate immigrants, the longer the immigration process continues. ${ }^{11}$

The following three examples of restrictive legal measures against veil wearing by immigrants or potential immigrants, clearly delineate the separation of the immigration

${ }^{10}$ On thin multiculturalism generally, see Yael Tamir, Two Concepts of Multiculturalism, $29 \mathrm{~J}$. PHIL. Edu. 161 (1995).

"This has been the case in Germany where the government kept insisting that "Germany is not a country of immigration," while at the same time it has de facto become the chief destination for migrants in the 1990s, see Contested Citizenship: Immigration and Cultural Diversity in Europe 1 (Ruud Koopmans et al. eds., 2005). 
process into three different stages: Stage I: Denial of immigrant status and an entry visa to any woman wearing a veil. To date, no state has in fact adopted this type of immigration policy, although France did in one instance deny an entry visa to a woman who refused to remove her veil for a security check. ${ }^{12}$

Stage II: Refusal of citizenship status to immigrant women wearing the veil. Faiza Silmi, for example - a thirty-two year old Moroccan woman, married to a French citizen and mother of four children, who is fluent in French and has resided in France since 2000-was denied French citizenship for wearing a burqa that covers her body from head to toe leaving only a narrow slit for her eyes. Recently, France's Constitutional Court, the Counseil d'Etat, affirmed the French government's refusal to grant Silmi citizenship and reasoned that she has adopted a radical practice of her religion that is incompatible with the core values of French society, in particular the principle of gender equality, and consequently, she has not met the condition of assimilation set out in Article 21-4 of the French Civil Code. ${ }^{13}$ According to the government commissioner who reported to the Counseil d'Etat on the case, in interviews with social services Silmi revealed that "[s]he lives in total submission to her male relatives. She seems to find this normal, and the idea of challenging it has never crossed her mind." ${ }^{\prime 14}$ Although her request for citizenship was denied, Ms. Silmi did not lose her right to reside in France. ${ }^{15}$

Stage III: Restriction of the right of women residing in its territory to wear the veil in certain places or circumstances. The French law enacted in February 2004 prohibits all public school students from wearing "conspicuous" religious symbols. ${ }^{16}$ While the law targets religious symbols that include the Jewish skullcap and large crosses as well, its chief objective was to prevent Muslim students from wearing the veil in public schools. ${ }^{17}$ The law applies to all Muslim public school students, regardless of their status; and thus includes first and second-generation immigrants as

${ }^{12}$ In a recent European Court of Human Rights decision, the Court affirmed France's denial of entry to a woman who had refused to remove her veil for a security check at the French consulate where she sought to apply for an entry visa to join her French husband in France. El Morsli - France, App. No. 15585/06, Decision Mar. 4, 2008.

${ }^{13}$ CE, June 27, 2008, Rec. Lebon 286798.

${ }^{14}$ Katrin Bennhold, A Veil Closes France's Door to Citizenship, N.Y. Times, July 19, 2008, available at http://www.nytimes.com/2008/07/19/world/europe/19france.html?ei=5070\&en=7b38a $50 \mathrm{f} 656 \mathrm{~d} 9 \mathrm{efa} \& \mathrm{ex}=1217131200 \& \mathrm{emc}=$ eta1 \&pagewanted $=$ all.

${ }^{15} \mathrm{Id}$.

${ }^{16}$ Law 2004-228 of 15 March 2004; Journal Officiel No. 65, Mar. 17, 2004, at 5190.

${ }^{17}$ Elaine R. Thomas, Keeping Identity at a Distance: Explaining France's New Legal Restrictions on the Islamic Headscarf, 29 Ethnic \& Racial Stud. 237, 237 (2006). 
well as native French citizens who converted to Islam. With that said, it is important to remember that the majority of the four-to-five million Muslims currently living in France are immigrants and the descendants of immigrants with about one-half of them foreign nationals. ${ }^{18}$ In a similar move, eight of the German states (landers) have passed laws prohibiting Muslim public school teachers from wearing the veil in school. The German Constitutional Court ruled inter alia that teachers may be prohibited from wearing the veil in public schools if the prohibition has a clear statutory foundation. ${ }^{19}$ It is important to note that whereas the French ban applies to students as well, in Germany the ban is narrower and only applies to teachers, who are public servants. In 2007, the United Kingdom Department for Education and Skills issued an uniforms guidance permitting schools to ban the full face niqab on safety, security, and effective learning grounds. ${ }^{20}$ While such restrictions can also be applied to nonimmigrant minorities, the immigrant status of the affected minority affects the normative analysis of the validity of these restrictions.

The importance of separately considering the three stages of the immigration process derives from the fact that at each stage the relevant rights and interests of both the immigrant and receiving communities vary considerably: Stage I: Currently, immigration is not recognized as a universal right under either law or in political theory. ${ }^{21}$ Thus, a potential immigrant, unless a refugee, does not have much of a case when claiming a right to entry into a receiving country ${ }^{22}$ This would seem to imply that a receiving state has the right to refuse entry to a woman merely because she is wearing the veil. Nevertheless, the lack of recognition of a universal immigration right does not allow receiving states to differentiate among potential immigrants according to any criteria they wish. Some argue that arbitrary immigration restrictions are unethical and restrictions must be based on compelling grounds. ${ }^{23}$ While it is generally conceded that receiving states can rightfully control the influx of people into

${ }^{18}$ John R. Bowen, Why the French Don't Like Headscarves: Islam, the State and Public Space 50-51 (2007).

${ }^{19}$ Fereshta Ludin Case, BverfG, 2 BvR 1436/02, Sept. 24, 2003; Christian Joppke, State Neutrality and Islamic Headscarf Laws in France and Germany, 36 Theoretical Soc. 313, 329-32 (2007).

${ }^{20}$ Schools Allowed to Ban Face Veils, BBC News, Mar, 20, 2007, available at http://news.bbc. co.uk/2/hi/uk_news/education/6466221.stm.

${ }^{21}$ Miller, infra note 36, at 196-99 (on the right to immigration).

${ }^{22}$ Article 14 of the Universal Declaration on Human Rights, 1948, G.A. res. 217A (III), U.N. Doc A/810 at 71 (1948); United Nations Convention Relating to the Status of Refugees, July 28, 1951, 1989 U.N.T.S. 137.

${ }^{23}$ Miller, infra note 36, at 199. 
their territories and that, for example, the economic skills of potential immigrants are a justified criterion for entry, the question of whether cultural and religious affiliation or practices can be considered justified is far more controversial. ${ }^{24}$

Stage II: Similarly, as there is no right to immigration, there is no right to naturalization as well. ${ }^{25}$ It can be opined that a state has an even stronger interest in, and entitlement to, controlling naturalization than controlling immigration since the right to entry is relatively easier to revoke than citizenship. Consequently, it could be argued that even if a receiving state cannot refuse entry to a woman wearing the veil, it is entitled to refuse her naturalization on this ground as seen in the circumstances surrounding the El Morsli-France case. While French authorities allowed Silmi into the country, despite her practice of wearing the burqa, they were entitled to refuse to grant her citizenship due to that same practice.

It is, however, important to note that once a person has legally immigrated into a country and has made it her home, her interest in remaining in that country and turning it into her permanent home increases. Seemingly, a woman who has already lived in France for five years and has raised a family there, prior to applying for naturalization, has a much stronger interest in obtaining French citizenship than a potential immigrant who has yet to create a life in France. Aware of the existence of these strong interests in the Faiza Silmi case - as well as of the parallel rights of her husband and children, French citizens, not to be separated from her-the French authorities have allowed Silmi to remain in France, albeit not as a citizen.

Many scholars have criticized this practice of creating a class of denizens by permitting people to live within the state's territory but preventing them from acquiring citizenship. Even Walzer, who asserts that the community wields absolute power to decide who may and may not enter its boundaries, argues that once inside those boundaries, all persons must be treated equally and, ultimately, be accorded equal status. He notes that otherwise, the community is transformed into tyranny with those who are members and those who are subjects. ${ }^{26}$ Similarly, Carens posits that once immigrants have resided in a country for several years, they acquire a right to receive

\footnotetext{
${ }^{24}$ This issue is raised infra Part II, which focuses on immigration and cultural rights, and will be applied to the specific context of the veil in Part V.

${ }^{25}$ States have very limited obligations with respect to granting nationality, and these apply strictly to stateless persons, and are enumerated in the Convention on the Reduction of Statelessness (Aug. 30, 1961, 989 U.N.T.S. 175) in pursuance of General Assembly Resolution No. 896 (IX) (Dec. 4, 1954) (entry into force December 13, 1975)). For an argument for a broader right to citizenship, see Joseph Carens, Immigration, Democracy, and Citizenship, in Of States, Rights, and Social Closure: Governing Migration and CitizenshiP 17 (Oliver Schmidtke \& Saime Ozcurumez, eds., 2007).

${ }^{26}$ WALZER infra note 53, at 52-61.
} 
citizenship and that the exclusion of immigrants and their children from citizenship cannot be reconciled with the principle of democratic legitimacy, which requires the consent of the governed. "To exclude people from citizenship is to fail to treat them as free moral agents with a right to participate in the collective determination of the laws to which they are subject." ${ }^{27}$ Thus, the right of those already residing in the country to be naturalized is considerably stronger than was their right to entry into that country and has ramifications for the appropriate balancing of rights and interests in determining whether to allow the naturalization of women wearing the veil. However, the weightier right of naturalization should also affect decisions made at Stage I of the process, when the rights and interests of the receiving state appear to outweigh the rights and interests of potential immigrants.

Stage III: Unlike Stages I and II, where immigrants have, at best, qualified rights, in Stage III of the immigration process, immigrants legally reside within the receiving state and are often citizens, and are equally entitled to exercise fundamental rights and freedoms, such as freedom of religion, as are all other residents of the state. Consequently, the clash of rights and interests generated by wearing the veil within the receiving country should be assessed quite differently in Stage III than in Stages I and II. Nonetheless, as is argued in greater detail in Part II, immigration does impact the scope of immigrants' right to culture in the receiving state.

\section{IMMIGRATION AND CULTURE}

The right to culture is a relative newcomer in the human rights discourse, and its justifications, scope, and proper application are fiercely debated. Liberal multiculturalists such as Kymlicka tend to justify the need to recognize the right to culture with the rationale that "cultural membership provides us with an intelligible context of choice" without which we cannot fully exercise our autonomy. ${ }^{28}$ Others, such as Taylor, argue that culture is the basis of identity, and consequently, society must respect minority cultures as a prerequisite for the successful formation of the identity of members of those minorities as well as their self-realization. ${ }^{29}$ Indeed, the main thrust of multicultural theory has been to provide a theoretical justification for the cultural accommodation of minority groups such as indigenous people and national

${ }^{27}$ Carens, supra note 25, at 20-21; see also MiLler, infra note 60, at 7-8.

${ }^{28}$ Will Kymlicka, Multicultural Citizenship 105 (1995).

${ }^{29}$ Charles Taylor, The Politics of Recognition, in Multiculturalism: Examining the Politics of RECOGNITION 25, 25-26 (Amy Gutmann ed., 1994). 
minorities. In recent years, especially in the context of mass immigration, the right to culture has been invoked by immigrant groups demanding cultural accommodation in the receiving countries, as well as by majority groups in those same countries in defending restrictions on immigrant groups aimed at preserving the culture of the majority.

\section{A. The Right of Immigrants to Culture}

The first question to be addressed is whether, and to what extent, immigrant groups are entitled to the right to preserve their culture in the receiving country. A plausible argument opines that because immigrants choose freely to immigrate to a foreign country, culturally different than their own, they are not entitled to such a right, but rather have a duty to integrate into the predominant public national culture and to change their own cultural practices in order to do so. Furthermore, it has been maintained that not only do multicultural policies fail to promote immigrant integration, they actually hinder it by encouraging "ethnic separatism." ${ }^{30}$ Thus, even if indigenous people and national minorities have a justified claim to some form of separatism and preservation of their distinctiveness, no such claim can be made by immigrant minorities, who must strive toward complete integration in the receiving community. Proponents of this argument may note that even avid multiculturalists such as Kymlicka, distinguish between indigenous people and national minorities, on the one hand, and immigrant communities, on the other hand, in terms of the scope and purpose of the cultural rights that they can claim. For example, according to Kymlicka, whereas multicultural policies relating to indigenous people and national minorities should enable them to sustain themselves as distinct communities within the broader society, multicultural policies directed at immigrants should be limited to enabling them to successfully integrate into the receiving society and mainstream institutions. ${ }^{31}$ According to Kymlicka's position, which I myself espouse, integration of immigrants should be through "fair terms of integration," which entail granting immigrants accommodation rights, such as the right to have dress codes and work schedules revised to accommodate religious beliefs. These rights are important not only as a show of respect toward immigrants' identities but also to ensure that

\footnotetext{
${ }^{30}$ Will Kymlicka, Politics in the Vernacular 152 (2001).

${ }^{31}$ Will Kymlicka, Do We Need a Liberal Theory of Minority Rights? Reply to Carens, Young, Parekh and Forst, 4 Constellations 72, 76-77 (1997). For criticism of this stance, see Joseph Carens, Iris Marion Young, Bhikhu Parekh, and Rainer Forst articles in supra.
} 
immigrants receive equal opportunity to fully participate in the economic and political institutions of the receiving society. ${ }^{32}$

\section{B. The Right to Culture of the Receiving Community}

The second question to consider is whether the receiving majority community has a right to culture and if so, by what means can it justifiably protect it. In Europe, the claim to such a right has been used to justify restrictions on the wearing of the Muslim veil in public. In France, for example, the law prohibiting public school students from wearing a veil at school has been justified as upholding the principle of laïcité (secularism), which is one of the central values of French national culture. ${ }^{33}$ Similarly, in Germany, most state laws forbidding public school teachers from wearing religious symbols - legislated in order to ensure the nonreligious nature of the state-include specific exemptions for Christian (and Jewish) religious symbols, which are part of the dominant culture. Accordingly, the Baden-Wurttemberg legislation declares that, "the representation of Christian and Occidental values and traditions corresponds to the educational mandate of the (Land) constitution" and does not undermine the principle of state neutrality. ${ }^{34}$

Although multicultural theory has been developed to justify the recognition of minority groups' cultural claims, the same reasons that support the importance of culture to the individual and the group equally apply to both minority and majority communities. Accordingly, the majority community has as strong an interest in preserving its culture as do minority groups. ${ }^{35}$ Nevertheless, this statement does not make any conclusion regarding measures that the majority may justifiably use to protect its own culture. The liberal multicultural theory has focused on the state's protection of minority cultures because of the differential power relationship existing between minorities and the majority, which enables the latter to entrench its culture in the state apparatuses and institutions while expressing and protecting that culture through public institutions all the time eroding minority cultures. ${ }^{36}$ From this it can

\footnotetext{
${ }^{32}$ KYMLICKA, supra note 30, at 162-63; KYMLICKA, supra note 28, at 31.

${ }^{33}$ See, e.g., Casanova supra note 1, at 9-10.

${ }^{34}$ Joppke, supra note 19, at 331-32. The text of the legislation is quoted id. at 332.

${ }^{35}$ David Miller, Immigration: The Case for Limits, in Contemporary Debates in Applied Ethics 193, 199-201 (Andrew I. Cohen \& Christopher Heath Wellman eds., 2005).

${ }^{36}$ As Shachar explains, "[a]t the heart of many contemporary justifications for multicultural citizenship lies a deep concern about power, particularly about the power of the state and dominant social groups to erode minority cultures." Ayelet Shachar, Multicultural Jurisdictions: Cultural DiFFERENCES AND WOMEN's Rights 22-23 (2001).
} 
be concluded that the majority is entitled to take measures to protect its culture as long as these measures do not infringe on the equal right of immigrants to preserve their culture, which entitles immigrants to receive accommodation rights within the framework of fair terms of integration.

\section{Which Culture?}

Other questions that need to be asked that pertain to the majority's right to culture are: which culture do they seek to protect and is the protection of certain forms of culture more legitimate than the protection of others. It is important to clarify from the outset that this discussion does not hold culture to have a fixed and clearly identifiable essence. Quite the contrary: Culture is indeterminate and in a constant state of flux; moreover, it is often difficult to discern the exact origin of various cultural precepts or customs. ${ }^{37}$ However, this does not alter the fact that in the European countries in which the cultural integration of Muslim immigrants is currently most strongly debated (France, Germany, Britain, the Netherlands, and Denmark), three separate yet interlinked strands of culture can be identified: Christian culture, secular culture, and liberal culture. ${ }^{38}$ Secular culture, or secularism, is often equated with liberal values, such as separation of church and state and state neutrality. Similarly, it is often argued that liberalism, specifically the principle of separation of church and state and the notion of the secular, originate in Christianity. ${ }^{39}$ Nevertheless, there are important differences between these three value systems. One value system justifies restrictions on wearing the veil with the need to protect Christian culture; the other grounds such restrictions on the need to protect secular culture; and the third asserts them to be necessary for upholding liberal values. The interesting question is whether there is any moral difference between these three forms of justification? Can the efforts to preserve Christian culture be regarded as a violation of freedom of religion and an attempt to impose Christianity on Muslims? Is the desire to safeguard secular culture

${ }^{37}$ Miller, supra note 35, at 126-30; KYMLicKA, supra note 28, at 101-05.

${ }^{38}$ See, e.g., Casanova, supra note 1, at 1 . A good example is the French insistence that the ban on the veil is intended to preserve laïcité in France, which is the French version of the secular state and of state neutrality in the public sphere. However, critics of the ban have argued that French laïcité should actually be termed "catholaïcité" because its neutrality is best suited to accommodate Catholic practices (for example, national holidays coincide with Christian holidays) and not Muslim or Jewish ones (such as wearing a veil or skullcap). Etienne Balibar, Dissonances within Laïcité, 11 Constellations 354, 363 n.4 (2004).

${ }^{39}$ Taylor, supra note 29 , at 62 . 
any less problematic because it requires state religious neutrality? Does the insistence on liberal values amount to the imposition of a particular type of Western culture, or is it indeed the promotion of universal values? While addressing these highly complex questions is beyond the scope of this Article, two important points should be made here: The first relates to the difference between protecting secular and Christian culture and the second pertains to the contention that liberal values are a cultural construct.

The question of whether it is more legitimate to aspire to preserve the secular culture of a state than its Christian culture must be analyzed on two levels: the symbolicrhetorical level and the level of state practice. The rhetoric in support of preserving a secular culture of state religious neutrality is more inclusive than that espousing preservation of the state's Christian culture. While any religion is particularistic, in that it distinguishes between followers and non-followers, state religious neutrality is aimed at eliminating such distinctions and enabling the equal coexistence of all religions. This is an important difference, particularly given the fact that a central rationale for the separation of church and state is the need to prevent religious strife. ${ }^{40}$ Yet some liberal democracies, such as England, in fact have official state churches, and this is not perceived, in and of itself, as a violation of the religious freedom of adherents of other religions. Thus, rather than the rhetoric, what should be of concern is the practical measures the state takes to preserve Christian culture. Furthermore, while in theory, the ideal of upholding a secular culture of state religious neutrality is commendable, in practice, certain interpretations of secularity and religious neutrality might inherently generate exclusionary measures as is discussed further on in the Article. $^{41}$

The claim that the insistence of liberal states on upholding liberal values, such as democracy and human rights, represents cultural imperialism and is an unwarranted imposition of liberal culture on immigrant minorities appears to be without merit. For while values such as democracy and human rights can be described as part of liberal culture, they are hardly mere cultural representations, but rather foundations in the attainment of justice, including justice in immigration. Immigration is a reciprocal process. Kymlicka's expression "fair terms of integration" conveys the notion that immigrants have an obligation to integrate into the receiving community and accept

\footnotetext{
${ }^{40}$ Kathleen Sullivan, Religion and Liberal Democracy, 59 U. CHI. L. Rev. 195, 198 (1992).

${ }^{41}$ See the discussion infra Part III on the distinction between liberal neutrality and republican neutrality and its implications for the rights of immigrant minorities.
} 
its fundamentally liberal framework of democratic governance and respect for basic rights and freedoms; at the same time they are entitled to expect that the receiving community will make the necessary adaptations to facilitate their integration and protect their right to equality and religious freedom as well as respect their culture. ${ }^{42}$ Miller takes a similar line, positing that immigration is a quasi-contract and, while the state, for its part, must guarantee immigrants full, equal citizenship, it is entitled to demand that they "accept the basic principles of liberal democracy" and "abandon practices that liberalism condemns [such as] practices involving the oppression of women, intolerance of other faiths, and the like." ${ }^{43}$ Thus, immigration emerges as a reciprocal process that creates duties for both sides. Immigrants expect receiving communities to respect their right to equality, religious freedom, culture, and full participation in society. In return, they must acknowledge their reciprocal duty to respect those same rights and freedoms for all others. This has the strongest force with regard to those who immigrate voluntarily, ${ }^{44}$ but it is also valid with respect to non-voluntary immigrants, such as refugees, for it is the receiving community's recognition of the human rights and fundamental freedoms of the immigrants that has enabled their immigration to the receiving country and their situation therein.

Immigrants can thus be justifiably expected to embrace liberal values but the question remains in which form? Should they be required to adopt liberalism as a comprehensive doctrine or only principles of political liberalism, such as those developed by Rawls? ${ }^{45}$ I contend that immigrants should be required to accept only the principles of political liberalism: Namely, the constitutional principles that uphold basic civil liberties and the democratic process that will be sufficient to ensure the continued existence over time of "a just and stable society of free and equal citizens," which remains divided by reasonable comprehensive doctrines. ${ }^{46}$ Moreover, the citizens of the receiving liberal states are themselves only required to accept principles of political liberalism and not liberalism as a comprehensive doctrine. Since reciprocity is a constitutive notion of both political liberalism and the immigration process, it seems unjustified to require either more or less of immigrants than of citizens. This is in line with Bassam Tibi's approach in the context of Muslim integration in Europe, rejecting the cultural relativist approach that negates common

${ }^{42}$ For example, by way of such measures as revising dress codes and work schedules to accommodate their religious practices. KYMLICKA, supra note 30, at 162-76.

${ }^{43}$ Miller, infra note 60 , at 14-15.

${ }^{44}$ KYMLICKA, supra note 30, at 170.

${ }^{45}$ John Rawls, Political Liberalism (1996).

${ }^{46} I d$. at 4. 
values and espouses different laws and different state treatment for different cultural communities; he calls instead for cultural pluralism that "combines cultural diversity with a consensus over core values." $" 47$ Tibi holds that both Muslim immigrants and Europeans must show "unequivocal and binding acceptance of the core European values of secular democracy, individual human rights of men and women, secular tolerance and civil society, ${ }^{\prime 48}$ observing that Europeans currently do not practice the values they preach and, as a consequence, Muslims in Europe suffer from exclusion and marginalization. ${ }^{49}$

To conclude, when considering whether receiving communities are entitled to impose certain duties or restrictions on immigrants' culture in the name of protecting their own culture, it is crucial to weigh both the rhetorical and practical implications of the specific duty or constraint, to ascertain whether it infringes upon the given immigrant community's right to the respect and accommodation of its culture from the receiving culture or upon its equal opportunity to participate fully in the economic and political institutions of the receiving society, all subject to the immigrant's duty to respect liberal values such as democracy and human rights.

\section{The Protection of Culture through Restrictions on Immigration}

The final question to be addressed in the context of cultural rights is whether states can restrict immigration in an attempt to protect their culture. As already discussed, there is no recognized right to immigration, ${ }^{50}$ Yet, with that said, a receiving state is entitled to differentiate between potential immigrants, but is not allowed to do so according to any criteria it chooses. Thus, while scholars generally agree that state governments are charged with the safeguarding the viability of national cultures, their views differ on the matter of whether restrictions on immigration are justified in principle to protect

\footnotetext{
${ }^{47}$ Bassam Tibi, Political Islam, World Politics and Europe: Democratic Peace and Euro-Islam versus Global JiHAD 212 (2008).

${ }^{48} I d$. at 215.

${ }^{49}$ Bassam Tibi, A Migration Story: From Muslim Immigrants to European "Citizens of the Heart?," 31 Fletcher Forum World AfFairs 147, 148 (2007).

In a similar vein, the recent European Pact on Immigration and Asylum expresses the view of the Council of the European Union that Member States can demand respect for "their fundamental values, such as human rights, freedom of opinion, democracy, tolerance, equality between men and women, and the compulsory schooling of children," while calling upon states to "combat any forms of discrimination to which migrants may be exposed." Council of the European Union, European Pact on Immigration and Asylum, Sept. 24, 2008.

${ }^{50}$ Miller, supra note 35 , at 196-99 (on the right to immigration).
} 
national culture and, if so, what form can these restrictions take. ${ }^{51}$ Some scholars have argued that culture as a criterion for immigration is merely a proxy for racism and the exclusion of certain ethnic and religious minorities. ${ }^{52}$ In contrast, one of the prominent rationales for restricting immigration on cultural grounds, propounded by Michael Walzer, is that "[a]dmission and exclusion are at the core of communal independence. They suggest the deepest meaning of self-determination. Without them, there could not be communities of character, historically stable, ongoing associations of men and women with some special commitment to one another and some special sense of their common life." ${ }^{53}$ Accordingly, Walzer advocates according the community an almost absolute right to choose who may enter. ${ }^{54}$ More nuanced views exist between these two polar stances and differentiate between countries in terms of the extent to which culture can be justifiably used as an immigration criterion, based on their type of communal identity. Coleman and Harding, for example, distinguish between countries on the basis of cultural and historical ties, which serve as a stronger justification for preference of those with similar ties to the state, and countries founded mainly on liberal political ideals, which have lesser justification for implementing a culturally discriminating immigration policy. ${ }^{55}$ For example, Coleman and Harding characterize

\footnotetext{
${ }^{51}$ Kymlicka, supra note 30, at 219. The belief that it is the task of the government to protect the national culture and that this justifies restrictions on immigration is held mostly by nationalists and liberal nationalists. Conversely, cosmopolitans, who do not view the state as defender of the national culture, generally subscribe to an open-borders immigration policy. Id. It is important to note that restrictions on immigration can take any number of forms, and probably the least controversial of which is setting a limit to the number of immigrants allowed entry. For the purposes of this discussion, I focus solely on immigration restrictions that are based on the culture of the immigrants and the receiving community.

52 Jean Hampton, Immigration, Identity, and Justice, in Justice IN Immigration 67, 84 (Warren F. Shwartz ed., 1995); see also Leti Volpp, The Culture of Citizenship, 8 TheOreTICAL InQ. L. 571, 580 (July 2007).

${ }^{53}$ Michael Walzer, Spheres of Justice: a Defense of Pluralism and Equality 62 (1983).

${ }^{54} \mathrm{Id}$. at 32 :

[W] who are already members do the choosing, in accordance with our own understanding of what membership means in our community and of what sort of a community we want to have. Membership as a social good is constituted by our understanding; its value is fixed by our work and conversation; and then we are in charge (who else could be in charge?) of its distribution.

For a critique of this stance, see Christian Joppke, Selecting by Origin 9-11 (2005).

${ }^{55}$ Jules Coleman \& Sara Harding, Citizenship, The Demands of Justice, and the Moral Relevance of Political Borders, in Justice IN IMMIGRATION, supra note 52, at 18, 52. Gans argues that granting special priority in immigration on the basis of nationality can be justified under certain conditions as a means of preserving the national culture of the group/s comprising the state. CHAIM GANS, THE Limits OF NATIONALISM 124-47 (2003).
} 
Germany and, to a lesser degree, France, as communities that maintain a strong cultural base, in contrast to the U.S. and Canada, which have political communities constructed on a plurality of cultures. ${ }^{56}$

A somewhat different theoretical middle-ground is sought by David Miller, who argues that states "require a common public culture that in part constitutes the political identity of their members, and that serves valuable functions in supporting democracy and other social goals"; ${ }^{57}$ accordingly, in a variety of circumstances, such as when the culture is endangered, some restrictions on immigration could be justified. However this notwithstanding, Miller posits that although there is no recognized right to immigration and states are allowed to control the influx of immigrants into their borders, immigration should be understood as a two-way contract between the immigrants and the receiving state, requiring of states, inter alia, that they adopt a fair immigration policy. ${ }^{58}$ Selecting immigrants by culture, he argues, cannot generally be considered fair, both because this places too much emphasis on the requirements of the receiving community and too little on the needs of the potential immigrants and because such a policy relies "on a too-rigid conception of national culture, underplaying the degree to which immigrant groups can contribute positively to a refashioning of that culture." 59 Thus, because national identity "is always in a flux, and is molded by the various sub-cultures that exist within the national society," there is no point in attempting to preserve an existing national identity or culture by refusing to admit immigrants who do not already share it. ${ }^{60}$

While Miller's emphasis on the need for fairness in immigration decisions seems sound, I opine that his dismissal of culture as a criterion for the selection of immigrants should perhaps be qualified. Using Coleman and Harding's distinction between countries with stronger cultural bases and countries that are founded mainly on political ideals, it could be argued that the fairness of according preference to immigrants on the basis of culture rests on the strength of the given country's cultural base. Thus, whereas it may be considered unfair for the U.S. to base immigration decisions on an immigrant's culture, this may be deemed fair when the country in question has a stronger cultural base such as France or Germany. Miller himself

${ }^{56} \mathrm{Id}$. at $49-51$.

${ }^{57}$ Miller, supra note 35, at 199-200.

${ }^{58}$ David Miller, Immigrants, Nations, and Citizenship, 16 J. Pol. PHIL. 371 (2008).

${ }^{59} I d$. An exception to this are circumstances in which some cultural aspect such as language is clearly at risk, Miller, supra note 35 , at 200.

${ }^{60}$ David Miller, on Nationality 128-29 (1995). 
seems to suggest this much when he offers Israel as an example of a country that should be allowed to continue to select immigrants on the basis of religion, because the Jewish religion still constitutes an essential part of Israel's public culture. ${ }^{61}$

However, even if it is legitimate to give preference to potential immigrants whose cultural background is similar to that of the receiving state, it is a different matter when a receiving country denies entry based on a determination that the applicant's specific culture is unsuitable for the country. Thus, while it may be fair for France or Germany to prefer immigrants with a French or German cultural background, respectively, this does not mean that it is fair for them to reject immigrants solely due to their Muslim cultural background or practices, such as veiling, which are an external symbol of that cultural background. Denial on this basis alone would appear to amount to racism and religious discrimination. ${ }^{62}$ Gans similarly distinguishes between giving priority to immigrants on the basis of cultural affinity and the categorical exclusion of anyone who does not share this cultural affinity. Thus, according to Gans, while a state in which a particular cultural group exercises its self-determination can give preference to immigrants with which it has a cultural affinity, it cannot categorically exclude all others. In his view, the only political entities that can justifiably exclude everyone except members of their own group are such entities as reservations for native minorities in Canada; for the latter, such exclusion is vital for preserving the traditional character of the public space. No country, not even one such as Israel, whose public culture is strongly based on Jewish culture and religion, can justify excluding all those who do not share its culture and religion. ${ }^{63}$ Considered together, these last two points seem to indicate that excluding immigrants solely on the basis of cultural divergence from the dominant culture in the receiving country can be justified only in extreme cases in which this is vital for sustaining a culturally distinct and endangered group

${ }^{61}$ Miller, supra note 35, at 204.

${ }^{62}$ Arguably, it will also be contrary to norms of international law. Article I(3) of the International Convention on the Elimination of all Forms of Racial Discrimination (660 U.N.T.S. 195 (Dec, $21,1965)$ ) states, "Nothing in this Convention may be interpreted as affecting in any way the legal provisions of States Parties concerning nationality, citizenship or naturalization, provided that such provisions do not discriminate against any particular nationality." According to General Recommendation No. 30: Discrimination Against Non Citizens, from January 2004 (General Recommendation: Discrimination against Non-Citizens. U.N. Doc. CERD/C/64/Misc 11/rev.3 (2004)) and issued by the Committee on the Elimination of Racial Discrimination, parties to the Convention must "[e]nsure that immigration policies do not have the effect of discriminating against persons on the basis of race, colour, descent, or national or ethnic origin." The recommendation is not binding.

${ }^{63}$ Chaim Gans, Nationalist Priorities and Restrictions in Immigration: The Case of Israel, 2 L. \& Eтнics Hum. RTs. 325 (2008). 
exercising its self-determination in the state, and only in the framework of a policy of general exclusion of immigrants who do not share this cultural background.

\section{Immigration And Religious Liberty}

The wearing of the veil by Muslim immigrants in Europe must be analyzed not only in terms of a clash of cultures, but also as a conflict between individual rights and liberties and certain state interests such as protecting state neutrality, laïcité and the public order. Because the wearing of the veil is perceived by many Muslims as a religious duty, a prohibition on wearing the veil infringes on the wearer's right to religious liberty. Nevertheless, various state interests have been put forward as justifications for this prohibition: the need to ensure state religious neutrality; the need to create a common public space in which the differences between citizens are not visible and that enables all citizens to mix socially and to participate equally (laïcité); and the need to protect the public order from the perceived threat of radical political Islam. An additional justification that is raised, women's right to equality and the state interest in guaranteeing that right, is discussed separately in Part IV.

Courts have ruled that these interests are compelling enough to justify constraints on a woman's religious freedom to wear the veil. In what follows I analyze three cases concerning the right to wear the veil in predominantly Christian countries: the recent Aktas case, in which the European Court of Human Rights (EctHR) affirmed the expulsion of a Muslim student from a French public school for failing to comply with the 2004 French law prohibiting the wearing of the veil and other conspicuous religious symbols; $;{ }^{64}$ the Dahlab case, in which the ECtHR ruled that Switzerland was justified in prohibiting a Muslim teacher from wearing the veil in school ${ }^{65}$ and the Ludin case, in which the German Constitutional Court held that the German states have the right to enact legislation that prohibits teachers from wearing headscarves to school. ${ }^{66}$ I use these cases as the framework for analyzing the justifications for infringing on Muslim women's religious liberty.

${ }^{64}$ Aktas v. France, App. No. 43563/08, June 302009.

${ }^{65}$ Dahlab v. Switzerland, 2001-V Eur. Ct. H.R. 449 (the applicant in Dahlab was a former Catholic who had converted to Islam and later married a Muslim immigrant).

${ }_{66}$ Entscheidungen des Bundesverfassungsgerichts [BverfG] [Federal Constitutional Court, September 24, 2003] Ludin Case (BverfG, 2 BvR 1436/02). Perhaps the most prominent case in which the European Court of Human Rights affirmed a state's ban on the veil is its decision in Sahin v. Turkey, 2005-XI Eur. Ct. H.R. 109 in which it affirmed Turkey's ban on students' wearing a veil 


\section{A. Religious Neutrality}

Both opponents and proponents of restrictions on wearing the veil invoke the principle of state religious neutrality in arguing their position, each side applying a different understanding of religious neutrality and its purpose. Opponents of restrictions emphasize the importance of religious neutrality as a means of protecting individual and minority rights, an approach referred to as "liberal neutrality." Proponents of restrictions on the veil espouse a conception of religious neutrality as intended to facilitate the constitution of a uniform public sphere that is considered neutral because it reflects the shared ideals of society, as opposed to the particular ideals of different groups. This approach is known as "republican neutrality." ${ }^{97}$ An important dimension of the latter approach is that in the attempt to limit the public sphere to shared values it can result in the restriction of religious freedom of individuals and minorities whose religious practices are not commonly shared. This was in fact the outcome in all three veiling cases noted above.

Article 9 of the European Convention on Human Rights (ECHR) ${ }^{68}$ which binds all European states, confers on all persons the right to freedom of thought, conscience, and religion, including the freedom to manifest religion or belief, in worship, teaching, practice, and observance. This notwithstanding, Section 2 of Article 9 provides that freedom to manifest one's religion or beliefs is subject to limitations prescribed by law and that are necessary in a democratic society to protect public safety, public order, health, morals, or the rights and freedoms of others. In its Dahlab decision, the ECtHR held that Article 9 represents one of the foundations of a democratic society. Regardless it accepted Switzerland's argument that the principles of denominational neutrality and religious harmony justified the restriction on the Muslim teacher's religious freedom and that the restriction on wearing the veil is necessary in a democratic society. ${ }^{69}$ While the Court found no evidence that the teacher's wearing of the veil for

at university. Nevertheless, since this case did not arise in the context of immigration it will not be discussed here.

${ }^{67}$ On the distinction between liberal neutrality and republican neutrality, see Joppke, supra note 19, at 316-17. See also John R. Bowen, Muslims and Citizens: France's Headscarf Controversy, Boston Rev., Feb./Mar. 2004. Bowen distinguishes between "liberal laïcité," which he associates with multicultural recognition of diversity, and "public laïcite," which he associates with the ideal of a shared republican citizenship.

${ }^{68}$ European Convention for the Protection of Human Rights and Fundamental Freedoms, arts. 1 \& 56, Nov. 4, 1950, 213 U.N.T.S. 222 [hereinafter ECHR].

${ }^{69}$ Dahlab v. Switzerland, supra note 65, at 11, 13. 
three years prior to the prohibition had affected the quality of her teaching or had led to any disruption or complaints from parents, ${ }^{70}$ it nonetheless accepted Switzerland's claim that the veil is a "powerful external symbol" whose impact on young children is difficult to assess. ${ }^{71}$ Invoking the margin of appreciation doctrine, which gives considerable latitude to the state in resolving conflicts between individual rights and national interests, the Court ruled against the applicant. ${ }^{72}$ Such a ruling is hard to reconcile with the principles of liberal neutrality, which are founded on a premise of non-interference of the state in individual religious beliefs. The decision is, however, consistent with republican neutrality and its objective of a non-denominational public sphere where religion is invisible. This type of public sphere may, indeed, be suited to members of the Christian majority, who manifest their religion through less conspicuous external symbols such as crosses worn under their garments. It is illsuited, however, to Muslim adherents, especially Muslim women, who cannot conceal the external symbol of their religion in a similar way.

The Dahlab decision can be explained as the combined result of the relatively restrictive wording of Article 9 of the Convention and the broad margin of appreciation accorded to the state in ECtHR case law, which could be an obstacle to insisting that states pursue a liberal understanding of neutrality. Such constraints, however, were not present in the German Ludin case. Unlike Article 9, which prescribes the conditions under which religious freedom can be restricted, Article 4 of the German Basic Law sets no limits on the protection of either religious faith or religious practice, although the absoluteness of this constitutional right was somewhat constricted by the German Constitutional Court in a decision that preceded Ludin. ${ }^{73}$ But despite this expansive

${ }^{70} \mathrm{Id}$.

${ }^{71} I d$. The applicant was teaching children between the ages of four and eight.

${ }^{72} \mathrm{On}$ the margin of appreciation doctrine, see Onder Bakircioglu, The Application of the Margin of Appreciation Doctrine in Freedom of Expression and Public Morality Cases, 8 Ger. L. J. 711 (2007).

${ }^{73}$ Grundgesetz für die Bundesrepublik Deutschland (Basic Law) arts. 4 (1) \& (2) prescribe as follows: "(1) Freedom of faith and of conscience, and freedom to profess a religious or philosophical creed, shall be inviolable. (2) The undisturbed practice of religion shall be guaranteed." While the constitutional guarantee of religious liberty in Germany is far more stringent than at the European level, the German Constitutional Court has held that it is not an absolute freedom and that restrictions are permissible, although they must " follow from the Constitution itself" and ... the legislature could not impose limits beyond what was envisaged by the constitution." Oliver Gerstenberg, Germany: Freedom of Conscience in Public Schools, 3 InT. J. Const. L. 94, 95 (2005) (quoting the 1995 crucifixes decision in which the Court prohibited the presence of crucifixes in state classrooms, 1 BverfGE 1087/91, May 16, 1995). 
notion of religious freedom, the Ludin decision granted the German legislature broad discretion to enact restrictions on public school teachers' right to wear the veil.

On the legal theory level, the Ludin court rejected the state's attempt to define religious neutrality in a republican sense, stressing that under the German Constitution, the government must actively support the ability of all individuals, regardless of religious affiliation, to exercise their religious liberty. ${ }^{74}$ Thus, the Constitutional Court dismissed the school board's claim that allowing a public school teacher to wear a headscarf while teaching at school would be in violation of the state's duty to uphold religious neutrality. The Court reasoned that the principle of religious neutrality dictates that the government takes positive steps to sustain plurality and ensure mutual openness. ${ }^{75}$ Nevertheless, from a practical perspective, although it struck down the school board's decision to fire Ms. Ludin, the Court in fact cleared the way for the application of republican neutrality, in holding that any state can ban public school teachers from wearing religious symbols, provided that the ban is set forth in state legislation and does not discriminate amongst religions. ${ }^{76}$ It was in the wake of this decision that eight German states passed such a ban, with all but one exempting Christian and Occidental symbols. ${ }^{77}$ This outcome illustrates the problematic nature of republican neutrality, revealing how the values and symbols shared by the cultural majority are perceived as neutral and, therefore, welcome in the public sphere, whereas the values and symbols unique to minorities are deemed nonneutral and thus prohibited from the public sphere.

\section{B. French Lä̈cité: The Creation of a Common Public Space}

In France, laïcité, a similar but more far-reaching argument than religious neutrality, has been invoked to justify banning the veil, not only in public schools but even

\footnotetext{
${ }^{74}$ The German system of church-state relations is based on a principle of a church-state partnership, whereby the churches and state are partners in the endeavor to ensure a prosperous and stable German society. Moreover, in the German system, freedom of religion is understood as a positive freedom, meaning that the state has a positive duty to ensure that religious people and religious associations can exercise their religious freedom (Stephen V. Monsma \& J. Christopher Soper, The Challenge of Pluralism: Church and State in Five Democracies 155 (1997)). Accordingly, state religious neutrality is conceived of as a duty to support all religions without giving preference to any one religion. Thus, the German Constitution allows the state to grant religious associations the status of corporations under public law and permits these religious associations to levy taxes to finance their operations and to enjoy public subsidies. Article 137 (5), (6), of the German Constitution of 1919.

${ }^{75}$ Gerstenberg, supra note 73 , at 98.

${ }^{76}$ Id. at 96; Joppke, supra note 19, at 329.

${ }^{77}$ Joppke, supra note 19, at 331-32.
} 
in the entire public sphere. This unique French conception arose out of the French republic's historical hostility toward the Catholic Church and is based on three guiding principles: separation of church and state, the concept of the state as the protector of individuals against religious power, and the notion that religion should be relegated to the private sphere and all matters within the public sphere are limited to the secular. ${ }^{78}$ This primary principle of the French republic goes hand-in-hand with the French republican ideal that all citizens must embrace the same values in the public sphere so as to foster solidarity with one another as well as with the state society. This ideal was explained by then-Interior Minister Nicolas Sarcozy in 2003, when he declared that "freedom is the rule in the private sphere, republican conformity is the rule in the public sphere." ${ }^{\prime 9}$ It is the combination of laïcité and this ideal of shared public values that led to the enactment of the law banning veils in public schools. ${ }^{80}$ It should be noted that the idea of creating a common public space devoid of any religious elements is perceived by the French not only as part of the state interest in creating solidarity and social integration, but also as way of defending and ensuring equality for all citizens. ${ }^{81}$ Thus, in advocating the ban on the veil, two French feminists have suggested expanding it to the entire public sphere, arguing that laïcité creates "a neutral public space, free of any religious belief, where citizens develop under the same treatment, sharing common rights and duties, and a common good, all of which places them beyond discriminating differences." ${ }^{2}$

While there is wide support in France for the republican model of laïcité, there is also support for a democratic or open model of laïcité, which resembles the liberal model of state religious neutrality and allows the presence of religion in the public sphere. ${ }^{83}$ According to Bauberot, the democratic model of laïcité better reflects the historical development of laïcité and is in practice the model applied with regard to Christianity and Judaism, whereas the exclusionary republican model is directed only at Islam. ${ }^{84}$ In its 1989 decision, as well as in subsequent decisions, the Conseil d'etat,

${ }^{78}$ Joan Wallach Scott, The Politics of the Veil 97-99 (2007).

${ }^{79}$ Quoted in Bowen, supra note 18, at 157-58.

${ }^{80}$ S СоTт, supra note 78 , at 12-13, Bauberot, infra note 83.

${ }^{81}$ The French understanding of equality is based on the notion of equality through sameness. For this reason it is also prohibited under French law, for example, to record religion, ethnicity, or national origin in French censuses. Id. at 12.

${ }^{82}$ Bowen, supra note 18 , at 229.

${ }^{83}$ Jean Bauberot, Two Thresholds of Laicization, in SECULARISM AND ITS CRITICS 94, 133 (Rajeev Bhargava ed., 1998).

${ }^{84} \mathrm{Id}$. at $134-35$. 
leaning toward the democratic model of laïcité, had ruled that the wearing of veils in public schools was not in itself incompatible with laïcité, and that the wearing of religious insignia by pupils at school can be prohibited only if it can be established that the behavior of the pupil in question amounted to an act of pressure or proselytism or interfered with public order in the school. ${ }^{85}$ However, in 2004, following the recommendations of the Stasi Commission, which was appointed by the President of the French Republic to study the application of the principle of secularism in France, an amendment to the Education Act was passed. This amendment fully implemented the republican model of laïcité by prohibiting public school pupils from wearing conspicuous religious symbols, thereby banning any wearing of the Islamic veil in public schools. In the Aktas decision, when deliberating the expulsion of a Muslim girl from a French school on the basis of the 2004 law, for refusing to remove her veil, the ECtHR unquestioningly endorsed France's right to adopt a republican model of laïcité ${ }^{86}$ Continuing its line of reasoning from the Dahlab decision, ${ }^{87}$ the Aktas court held that member states should be granted a wide margin of appreciation in deciding what limits should be set on religious liberty to protect the rights and freedoms of others and to maintain public order, and that the 2004 law and its implementation did not violate Article 9 of the ECHR. ${ }^{88}$

Though the courts have affirmed the right of European states to embrace a republican model of state religious neutrality and of laïcité, it is questionable whether states' insistence on upholding these concepts is legitimate in societies that, to boost their economies, have already admitted a large number of Muslim immigrants whose religious practices conflict with these concepts. The sheer size of these immigrant communities in European states sharply highlights the problematic and contradictory nature of these concepts, exposing the fact that the public sphere that they create is suited to the particular religious practices of the majority population and therefore not truly neutral. If religious neutrality and, in France laïcité are intentionally used to discriminate against Muslims and to constrain their religious freedom, as some suggest, then they cannot be considered as serving legitimate state interests in

\footnotetext{
${ }^{85}$ For a concise description of the legal developments surrounding the wearing of veils in public schools in France, including Conseil d'etat decisions, the Stasi Commission and the 2004 amendment to the Education Act, see Dogru v. France (Application No. 27058/05), 4 December 2008 sections 17-32.

${ }^{86} \mathrm{Id}$.

${ }^{87}$ Dahlab v. Switzerland, supra note 65.

${ }^{88}$ Dorgu v. France, supra note 85 , at $17,19-20$.
} 
societies founded upon respect for human rights and non-discrimination. Perhaps discrimination against Muslims generated by these concepts, in restricting their religious liberty while upholding that of others, is an unintended consequence of their historical development. This does not, however, render it legitimate, in light of its distinctly discriminatory effects and clear encroachment on religious liberty.

\section{Protecting the Public Order from the Perceived Threat of Radical Political Islam}

A third and final possible explanation for the ban on the veil is that it is part of the efforts to avert the danger posed by radical political Islam to public order. ${ }^{89}$ The right of democratic states to defend themselves against a threat to their democratic structure by taking steps that restrict individual rights is widely acknowledged, referred to at times as "militant democracy." 90 In order to protect its democratic nature against serious harm, a state is entitled to not only restrict the rights of its own population but also, and to an even greater extent, deny entry or naturalization to foreign citizens. However, for such restrictions or denials to be legitimate, they must be grounded on concrete evidence that the religious beliefs and practices of the applicant pose a direct threat to the democratic nature and liberal values of the state. Nevertheless, since there is no recognized right to immigration or naturalization, considerably less weighty evidence would be required for justifying a state's denial of entry to a potential immigrant, or of naturalization, than would be necessary for restrictions on the fundamental rights of its citizens.

Tibi argues that the threat of radical political Islam to European states is a serious one and that extremist Muslim leaders see Muslim immigration into Europe as an opportunity to bring about the Islamization of Europe. ${ }^{91}$ According to Tibi, for these leaders, the failed integration of Muslims in Europe is fertile ground to generate support among European Muslims for the Islamizing of Europe and the radical change of its

\footnotetext{
${ }^{89}$ This reasoning was not discussed by the ECtHR in the veil cases which arose from Muslim immigration into predominantly Christian countries. However, it was applied by the ECtHR in the Turkish Şahin case. In upholding the Turkish ban on the veil in universities, the Court relied, inter alia, on the existence of extremist political movements in Turkey, which seek to impose their religious conception of society on the general population. Sahin v. Turkey, supra note 66, sect. 115.

${ }^{90}$ On militant democracy, see Patrick Macklem, Militant Democracy, Legal Pluralism, and the Paradox of Self-Determination, University of Toronto Faculty of Law Legal Studies Research Paper No. 05-03, available at http://ssrn.com/abstract=702465.

${ }^{1}$ TIBI, supra note 47, at 188-90.
} 
democratic and human rights oriented system of governance. ${ }^{92}$ Given this peril, Tibi asserts that Europe has one of two options. Either, to change its cultural attitudes and become truly inclusive and thereby facilitate the integration of Muslim immigrants into Europe and the creation of "Euro-Islam," a form of Islam that allows Muslim immigrants to accept European values while at the same time remaining Muslim, or, be prepared to contend with the consequences of the intensification of Islamic extremism within European borders. ${ }^{93}$ Consequently, I would argue that, with respect to Muslim immigrants already residing in Europe, the appropriate means of safeguarding the public order from the spread of radical political Islam is to offer these immigrants fair terms of integration, which include accommodating their religious and cultural practices that do not infringe on liberal humanistic values.

\section{IMMIGRATION AND WOMEN's EQUALITY}

The issue of women's equality is a central component in the Muslim veiling debate. When scrutinizing the effects of veiling on women's rights, it is important to distinguish between its impact and connotations for women from Muslim communities and its implications and ramifications for the general right of European women to equality and the interest of European states to establish and maintain gender equality.

From a feminist perspective, the veil debate brings to the fore a familiar dilemma: What is the appropriate feminist response to a practice that originates in a patriarchal religion, was created and is controlled by men, and signifies women's modesty and their submission to the authority of God and his male representatives; yet, at the same time is lauded by some of those women adhering to it as a liberating, empowering, and a freely chosen expression of their religious and cultural identity? This conflict between the goal of eradicating oppressive norms to advance women's equality and the need to respect those same norms as manifestations of women's freedom of choice is a core issue in feminist theory. ${ }^{94}$

This dilemma is further complicated in the context of Muslim veiling by the fact that, in Europe, it is practiced by women who are part of a minority, mostly

${ }_{92}$ Id. at 215. See also Tibi, supra note 49, at 149-51 (discussing the dangers posed by radical political Islam).

${ }_{93}$ TIвI, supra note 47, at 213-15.

${ }^{94}$ See, e.g., the debate between Sawitri Saharso, Feminist Ethics, Autonomy and the Politics of Multiculturalism, 4 FEMINIST THEORY 199-215 (2003) and Clare Chambers, Autonomy and Equality in Cultural Perspective: Response to Sawitri Saharso, 5 FemINIST THEORY 329-32 ( 2004). 
immigrant, community. On the one hand, Muslim women in Europe are perhaps the weakest members of the entire state polity, exposed to both intersectional forms of discrimination due to their ethnic origin, religion, and sex, as well as discrimination within their own community. ${ }^{95}$ Consequently, they are almost powerless to resist in-group pressure to abide by the dictates of their traditional community. On the other hand, the discrimination these women experience from European society at large makes it all the more likely that they seek solace in religion and the traditions and customs of their community. Thus, the aspiration to respect minority practices while protecting the rights of the weaker members of the minority group, the "minority within the minority" - the female members of the Muslim communities in Europe - causes an intricate predicament. ${ }^{96}$ An additional complication in this context is the concern that radical political Islam uses the veil as a weapon in its bid for power and that those women are bullied into wearing the veil by the use of threats and physical force. ${ }^{97}$

The last point to be considered when analyzing the soundness of the ban on wearing the veil as a means of protecting women's right to equality is the varied and complex meanings that the wearing of the veil has for Muslim women. ${ }^{98}$ While some of these meanings sit uncomfortably with the notion of women's equality, others, such as the assertion of personal identity, are unrelated to it and may even be conducive to it.

${ }^{95}$ On intersectional discrimination against minority women, see Nira Yuval-Davis, Intersectionality, Citizenship and Contemporary Politics of Belonging, 10 CRI. Rev. INT'L Soc. \& Pol. PHIL. 10 561, 564-66 (2007).

${ }^{9}$ See, e.g., Susan Moller Okin, Is Multiculturalism Bad for Women? (1999); Ayelet Shachar, On Citizenship and Multicultural Vulnerability, 28 POL. THEORY 64 (2000).

${ }^{97}$ Patrick Weil, Lifting the Veil, 22 French Pol., Culture \& Soc. 2004. Weil, who was a member of the presidential commission that recommended the ban on the veil, describes the basis for his support for the recommendation:

[W] had to face a reality which was perceived at the local level, but not at the national nor obviously at the international one: wearing the scarf or imposing it upon others has become an issue not of individual freedom but of a national strategy of fundamentalist groups using public schools as their battleground.

See also Armando Salvatore, Authority in Question: Secularity, Republicanism and "Communitarianism" in the Emerging Euro-Islamic Public Sphere, 24 Theory, Culture \& Soc. 135,149 (2007).

${ }^{98}$ In one study, for example, it emerged that there are seven possible meanings to wearing this type of veil: 1) an act of religious faith, dictated by the wearer's conscience and expressed publicly; 2) protection against sexual objectification by men; 3 ) an expression of self-esteem and self-confidence as a Muslim woman; 4) an expression of belonging to the Islamic political movement; 5) a symbolic distinction between the wearer as a member of a minority and the non-veiled majority; 6 ) a personal statement against cultural modernity, including sexual equality; or, 7) an indication of the coercion of the woman to wear the veil and assume a Muslim woman's traditional role. See Sauer, supra note 2, at 4-5 (discussing a study by Monika Hoglinger made in 2002). 
While I do think that the veil, at least in its original meaning, is a symbol of women's oppression, it has clearly gained other, more liberating meanings for many women, and especially for Muslim women in Europe. ${ }^{99}$ Regardless, the problem with placing restrictions on the veil is not merely that such restrictions prevent women who wear the veil as a sign of independence and defiance from doing so, but, principally, that the restrictions do not actually further the goal of promoting equality for Muslim women, and thus, from the perspective of gender equality, are both futile and counterproductive.

From a feminist perspective, banning the veil is both a dismaying overreaction and a disheartening under-reaction to the common problems faced by many women in Muslim communities. The ban is an overreaction in that it disproportionally restricts Muslim women's religious freedom without improving their status within the Muslim community or wider society. The individuals who are directly harmed by the ban are Muslim women who wear the veil as part of their religious beliefs and who, as a result of the ban, are forced to choose between their faith and their employment opportunities (as teachers) or educational opportunities (as students). Furthermore, restrictions on wearing the veil reinforce the traditional patriarchal view that women are incapable of choosing for themselves and are in need of protection and guidance from the state. Yet, restrictions on the veil are an under-reaction insofar as that they fail to address the true underlying causes of women's inequality within the Muslim community as well as in society in general. ${ }^{100}$ Clearly, many Muslim women in European countries suffer oppression and discrimination in their homes and communities. This is most evident in extreme cases such as honor killings or forced marriages, but also valid with regard to the many young uneducated Muslim women brought to Europe from their home countries who are confined to their homes, lack any economic skills or

\footnotetext{
${ }^{99}$ For example, the majority of the German Constitutional Court in Ludin found that wearing the veil is not necessarily an expression of the subjugation of women and that it might also represent a religious symbol freely chosen by the woman in order to allow her to lead an autonomous life while still adhering to her religion. Gerstenberg, supra note 73, at 96. Similarly, Weil explains,

While for a majority of women the headscarf is the expression of the domination of women by men (this meaning was, for example, strongly expressed by many women refugees from Iran), it can be, and is, understood differently. It can also be the expression of a free belief, a means of protection against the pressure of males, an expression of identity and freedom against secular parents and against Western and secular society. Weil, supra note 97.

${ }^{100}$ On the condition of Muslim women in France, see Fadela Amara, Breaking the Silence (2006); for an interesting overview of the situation of Muslim women in France, Germany, and Britain, see Sylvia Poggioli, Exploring the Status of Muslim Women in Europe, NPR SERIES, January 2008, available at http://www.npr.org/templates/story/story.php?storyId=18330334.
} 
knowledge of the language, and are thus under the absolute control of their husbands. Restrictions on veil wearing can in no way alleviate this oppression. The measures required to combat these forms of oppression entail entering the private sphere in order to prevent abuses that occur there, severely punishing the abusers, empowering Muslim women in both the public and private spheres, and taking steps to counter the social and economic discrimination Muslims endure in receiving states. Banning the veil is no substitute for such measures. In fact, the ban has the very opposite effect of empowerment, pushing Muslim women back into the private sphere, far beyond the reach and protection of the state and employment and educational opportunities. Instead of prohibiting the veil and violating the rights of many Muslim women while leaving extremists free to exert pressure in other ways, the state must implement strong legal measures against extremists who compel women to wear the veil through threats or force.

\section{The Right to Wear the Veil at Each Stage of the Immigration PROCESS}

This Part draws together the different strands of the discussion to formulate a proposed analysis of the veiling practice and its impact on the rights and interests involved throughout the three stages of the immigration process.

\section{A. Stage I: Wearing the Veil and the Right to Entry}

The discussion in preceding parts led to the understanding that despite the fact that no right to immigration exists, states should adopt immigration policies that are fair ${ }^{101}$ and that while it is fair for a state constructed on particular cultural and historical ties to give preference to immigrants sharing that background, excluding immigrants solely on the basis of their belonging to a particular culture (such as Islamic culture) or of the fact that they follow a practice that symbolizes that culture (such as veiling) cannot be considered fair policy. Similarly, states cannot deny entry to applicants who wear the veil on the grounds that veil-wearing in the public sphere would threaten state religious neutrality or in France, laïcité. While wearing the veil in the public sphere may be incompatible with the republican understanding of religious neutrality or

${ }^{101}$ David Miller, Immigrants, Nations, and Citizenship, 16 J. PoL. PHIL. 371 (2008). See the discussion in supra II(D). 
laïcité, the discussion showed that the implementation of these principles results in the unjustified restriction of religious freedom and discrimination of minority residents of the state. They therefore, constitute illegitimate state policies that should be changed and cannot serve as a valid basis for exclusion in immigration. In contrast, wearing the veil in the public sphere is wholly compatible with the liberal understanding of state religious neutrality and the democratic model of laïcité, which espouse pluralism and the protection of minority rights in the public sphere. ${ }^{102}$

At the same time, it was further concluded that liberal states can legitimately insist that immigrants respect liberal values, particularly democracy and human rights. These values are not merely cultural constructs but, rather, comprise the ground rules for just social interactions between the state and its citizens, as well as for the interaction between immigrants and the state and demands immigrants can make of the state. ${ }^{103}$ Given this, would it be legitimate for states to refuse entry to applicants who might pose a threat to the human rights of their citizens and to democratic rule? Specifically, can a state legitimately assume that veiled immigration applicants would pose a threat to human rights and democratic rule, because the veil signifies adherence to the principles of radical political Islam and opposition to democratic rule and human rights? As already discussed, wearing the veil has many meanings, most of which - such as an act of religious faith or the assertion of self-identity-pose no threat to human rights or democratic rule. ${ }^{104}$ Thus, it appears unjust for a European state to presume, without any concrete evidence, that a woman applying to immigrate necessarily supports revolutionary ideas of political Islam and their implementation in Europe or would undermine religious liberty and women's equality, merely because she wears the veil.

I would nonetheless argue, however, that a much narrower restriction pertaining only to women wearing a burqa (fully covering the entire body including the face) and their male relatives could be justified on grounds of their rejection of liberal values. ${ }^{105}$ Unlike the veil, which is open to many interpretations, the full face burqa appears to have a single meaning, namely, a manifestation of the teachings of a highly patriarchal fundamentalist religious belief system in which women are fully subordinated to the authority of their husbands and other male relatives and must conceal themselves

\footnotetext{
${ }^{102}$ See supra Parts III(A) \& III(B).

${ }^{103}$ See supra Part II(C).

${ }^{104}$ See supra note 8 and accompanying text.

${ }^{105}$ This does not apply to refugees that the state has an explicit duty to receive.
} 
completely when venturing outside the confines of their homes. ${ }^{106}$ I would argue that the difference between the veil and the full face burqa is not merely a quantitative difference manifested by the extent of the covering, but a qualitative one. The notion that a person must cover herself completely, and erase her identity, to be allowed to venture into the public sphere, merely because she is a woman, is demeaning and dehumanizing. A belief system which denies women the right to identity in the public sphere cannot be reconciled with the principle of women's equality or other fundamental liberal values, such as human dignity and liberty and would therefore serve as a legitimate basis for rejecting potential immigrants who espouse it.

It should be noted that despite the considerable consensus as to the right of receiving countries to expect new immigrants to accept liberal values, basing immigration decisions on the potential immigrant's attitude towards liberal values is controversial. Thus, for example, Miller holds that while, in principle, selection on the basis of political values could be justified there are two practical reasons for objecting to such a policy. The first, he argues, is that unlike cultural values, political values are more malleable; therefore, immigrants' political values will be impacted by the exposure to liberal values in the receiving country. The second reason Miller submits is the concern that immigrants can easily lie regarding their political values, rendering them questionable as an immigration criterion. ${ }^{107}$ Yet it seems that these problems are less likely to arise in the context of the full face burqa as a proxy for rejection of liberal values. Regardless of whether political values are or are not as malleable as Miller maintains, the system of beliefs expressed by the burqa - those propounded by radical Islam - is not malleable and clearly stands in opposition to human equality, dignity, and liberty. For this reason, the commitment to wearing a burqa seems a fairly reliable indicator of the wearer's rejection of liberal values, and I would argue that unless she can prove otherwise, it can serve as reasonable grounds for denying entry to her and, even more so, her male relatives. ${ }^{108}$

${ }^{106}$ In the Silmi case, discussed in Part I (Stage II), the social services employee who interviewed Ms. Silmi for her naturalization application reported to the court that "[s]he lives in total submission to her male relatives. She seems to find this normal, and the idea of challenging it has never crossed her mind." Bennhold, supra note 14.

${ }^{107}$ MiLLer, supra note 60, at 19.

${ }^{108}$ Although some Muslim women in Europe have begun wearing the burqa as a political statement as to their identification with radical political Islam, this does not seem to detract from the validity of the argument, both because this phenomenon is true only of a small minority of women, already residing in Europe, and because the choice to embrace radical political Islam is in itself a resounding rejection of liberal values. 


\section{B. Stage II: Wearing the Veil and the Right to Citizenship}

In Part I, it is argued that an immigrant has at most, a qualified right to citizenship and, moreover, that the state in fact has a stronger interest in controlling naturalization than entry. However, it is further asserted, that the balance of rights at the stage of naturalization might tilt in the applicant's favor in those not-so-uncommon cases in which she has resided in the receiving state for a considerable number of years, and has forged ties and built a life for herself there. Furthermore if, as is shown in the previous section, a state cannot legitimately refuse entry to a woman for wearing the Muslim veil based on its right to preserve its culture or uphold its republican conception of state religious neutrality or laïcité, then it certainly cannot rely on those grounds to deny naturalization to women who wear the veil. And although we conclude that a receiving state has the right to reject immigration applicants who reject liberal values and can consider the full face burqa (as opposed to a regular veil) a proxy for such an anti-liberal stance, a similar conclusion does not necessarily follow with respect to the state's right to deny citizenship to immigrants already residing in the state, as in the case of Faiza Silmi. ${ }^{109}$ Immigrants who have built a life and family in the receiving country should not be denied citizenship and turned into denizens, without a compelling reason. ${ }^{110}$ Although wearing the burqa does point to a rejection of the liberal value system, unless it can be shown that the individual woman herself poses a serious threat to those values, she should not be refused naturalization. It should be noted that this argument bolsters the state's interest in denying entry to women wearing a full face burqa, since once they have entered the country, the balance of interests shifts toward allowing their naturalization, especially with the passage of time and the establishment of family ties in the receiving country.

\section{Stage III: Wearing the Veil within the Receiving State}

At first blush, the question of whether immigrants have a right to wear the veil in the receiving country seems to entail a clash between two equally weighty rights: immigrants' right to culture and the receiving community's right to culture. Both sides claim a right to express their culture in the public sphere. However, while the Muslim minority demands the right to maintain its cultural practice of wearing the veil

${ }^{109}$ Decision of Counseil d'Etat No. 286798, June 27, 2008. See the discussion of the case in Part I.

${ }^{110}$ See supra Part I. 
in the public sphere alongside the practices of the receiving community, the receiving majority asserts exclusive control over that public sphere to exclude the cultural practices of minority groups in that space. The latter's demand cannot be justified by its right to culture, for the implementation of such control is not strictly necessary for preserving the majority culture and, moreover, this violates the immigrant minority's right to culture. Thus, while the right to culture should in principle entitle individuals to a secure cultural context within which to develop their autonomy, identity, and sense of self, the existence of such a cultural context does not normally require the exclusion of all other cultures from the public sphere, especially when it is the majority culture seeking this exclusion. Excluding all other cultures from the public domain can be justified only in extreme circumstances of peril to the given culture. ${ }^{111}$

In our specific context, such exclusion infringes on the Muslim minority's right to culture because this right encompasses the individual's ability to express that culture in both the private and public spheres. Respecting a minority's right to culture in the public sphere by allowing its members to wear distinctive cultural and religious symbols is crucial for enabling their full and equal participation in the country's economic and social life. ${ }^{112}$ Thus, for example, banning the veil in public schools may very well hinder the education of Muslim girls, whose families will not allow them to go to school unveiled, or the career choices of young Muslim women, who might have sought to become school teachers were it not for the ban. Accordingly, the right of the majority community to protect its culture cannot serve as justification for preventing Muslim women from wearing the veil in the public sphere. Similarly, the interest in implementing the republican understanding of religious neutrality or model of laïcité cannot justify denying Muslim women the right to wear the veil in the public sphere. These interests in fact constitute an interest in maintaining a public sphere that manifests exclusively the culture and practices of the majority community, which have already been concluded to be illegitimate.

Quite insightful in the context of the ban on the veil as a means of controlling radical political Islam is Tibi's assessment that the failure of European states to show respect for Muslims and to integrate them into their societies is the cause of the rise of political Islam in Europe. This observation raises doubt as to whether banning the

III See, e.g., Miller, supra note 36, at 200; Na'ama Carmi, Immigration Policy: Between Demographic Considerations and Preservation of Culture, 2 L. \& Ethics Hum. RTs. 387, 391 (2008).

${ }^{112}$ Krmlicka, supra note 30 , at 31 . 
veil constitutes the apt response to the threat of political Islam or whether in fact it only serves to drive more moderate Muslims towards extremism.

Finally, as discussed in Part IV, restricting veiling does not promote the equality of Muslim women within the receiving country. Rather, other, far more extensive and comprehensive measures are needed to achieve this objective. Notwithstanding, the ban could be explained on the grounds that allowing Muslim women to wear the veil in the European public sphere erodes the right of all women to equality. Indeed, under this argument, allowing the presence of a "powerful external symbol" of women's oppression in the public sphere could have an adverse impact on the status of women by normalizing and legitimating the oppression of women when based on religious beliefs. As the argument goes, such legitimization will soon lead to a general legitimization of discrimination against women and to the loss of all the hard-won gains towards gender equality. While undoubtedly appealing, this line of argument is a tenuous one. There is insufficient factual data to assess the extent of the harm to women's equality, and mere speculations of this sort cannot constitute an appropriate basis for restricting Muslim women's religious freedom and right to equal opportunity. It thus, appears that receiving states' restrictions on the right of Muslim women to wear the veil cannot be justified on any of the aforementioned rationales.

\section{CONCLUSION}

Muslim veiling is a practice that was brought to Europe by immigrants and is adhered to mainly by immigrants and their offspring. In this Article, I have tried to unravel the various arguments and counterarguments raised in the controversy over the Muslim veil in Europe, in order to identify and assess the various rights and interests involved and analyze them in the context of the immigration process.

Over the course of my discussion, I conclude that the invoked state interests are not sufficient to justify restrictions on the right of Muslim women to wear the veil in the public sphere (Stage III of the immigration process) and, moreover, that these interests cannot justify a refusal to naturalize women who wear the veil (Stage II). With respect to the entry stage of immigration (Stage I), I show that the fact that a female applicant wears the veil cannot serve as grounds for denying her entry into the receiving country. However, I assert that it can be plausibly argued that refusing entry to women who wear the full face burqa and to their male relatives is justified by European states' right to deny entry to those who reject liberal values. Immigration into liberal states is a reciprocal process. It requires of receiving communities to accommodate foreign cultural and religious practices that do not violate fundamental 
2010] Rights in Immigration: The Veil as a Test Case

human rights and to integrate immigrants into their societies, while showing them equal concern and respect. At the same time, however, it requires of immigrants that they accept core liberal values. 